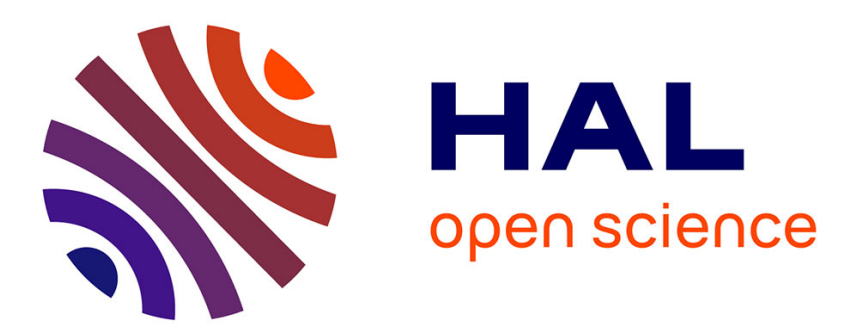

\title{
Light absorption properties and absorption budget of Southeast Pacific waters
}

Annick Bricaud, Marcel Babin, Hervé Claustre, Josephine Ras, Fanny Tieche

\section{To cite this version:}

Annick Bricaud, Marcel Babin, Hervé Claustre, Josephine Ras, Fanny Tieche. Light absorption properties and absorption budget of Southeast Pacific waters. JOURNAL OF GEOPHYSICAL RESEARCHOCEANS, 2010, 115, 10.1029/2009JC005517 . hal-03502060

\section{HAL Id: hal-03502060 https://hal.science/hal-03502060}

Submitted on 24 Dec 2021

HAL is a multi-disciplinary open access archive for the deposit and dissemination of scientific research documents, whether they are published or not. The documents may come from teaching and research institutions in France or abroad, or from public or private research centers.
L'archive ouverte pluridisciplinaire HAL, est destinée au dépôt et à la diffusion de documents scientifiques de niveau recherche, publiés ou non, émanant des établissements d'enseignement et de recherche français ou étrangers, des laboratoires publics ou privés.

$$
\text { Copyright }
$$




\title{
Light absorption properties and absorption budget of Southeast Pacific waters
}

\author{
Annick Bricaud, ${ }^{1}$ Marcel Babin, ${ }^{1}$ Hervé Claustre, ${ }^{1}$ Joséphine Ras, ${ }^{1}$ and Fanny Tièche ${ }^{1}$ \\ Received 13 May 2009; revised 7 December 2009; accepted 13 January 2010; published 7 August 2010.
}

[1] Absorption coefficients of phytoplankton, nonalgal particles (NAPs), and colored dissolved organic matter (CDOM), and their relative contributions to total light absorption, are essential variables for bio-optical and biogeochemical models. However, their actual variations in the open ocean remain poorly documented, particularly for clear waters because of the difficulty in measuring very low absorption coefficients. The Biogeochemistry and Optics South Pacific Experiment (BIOSOPE) cruise investigated a large range of oceanic regimes, from mesotrophic waters around the Marquesas Islands to hyperoligotrophic waters in the subtropical gyre and eutrophic waters in the upwelling area off Chile. The spectral absorption coefficients of phytoplankton and NAPs were determined using the filter technique, while the CDOM absorption coefficients were measured using a 2 m capillary waveguide. Over the whole transect, the absorption coefficients of both dissolved and particulate components covered approximately two orders of magnitude; in the gyre, they were among the lowest ever reported for open ocean waters. In the oligotrophic and mesotrophic waters, absorption coefficients of phytoplankton and NAPs were notably lower than those measured in other oceanic areas with similar chlorophyll contents, indicating some deviation from the standard chlorophyll-absorption relationships. The contribution of absorption by NAPs to total particulate absorption showed large vertical and horizontal variations. CDOM absorption coefficients covaried with algal biomass, albeit with a high scatter. The spectral slopes of both NAP and CDOM absorption revealed structured spatial variability in relation with the trophic conditions. The relative contributions of each component to total nonwater absorption were (at a given wavelength) weakly variable over the transect, at least within the euphotic layer.

Citation: Bricaud, A., M. Babin, H. Claustre, J. Ras, and F. Tièche (2010), Light absorption properties and absorption budget of Southeast Pacific waters, J. Geophys. Res., 115, C08009, doi:10.1029/2009JC005517.

\section{Introduction}

[2] Light absorption coefficients of the various marine substances (phytoplankton, nonalgal particles, and colored dissolved organic matter) are key parameters determining the optical variability of oceanic waters, as well as their reflectance properties, and the knowledge of their variations with environmental factors is one of the prerequisites to the refinement of bio-optical models. Therefore, the spectral absorption coefficients of particulate matter, and of their two components, phytoplankton and nonalgal particles (NAPs), have been widely studied in the world ocean over the past 2 decades. To represent the observed variations, simple parameterizations have been proposed. The most documented relationships relate particulate absorption $a_{p}(\lambda)$ or phytoplanktonic absorption $a_{\phi}(\lambda)$ to the chlorophyll concentration $\mathrm{Chl}$, the most commonly used index of algal biomass.

\footnotetext{
${ }^{1}$ Laboratoire d'Océanographie de Villefranche, Université Pierre et Marie Curie, Paris 6, CNRS, Villefranche-sur-Mer, France.

Copyright 2010 by the American Geophysical Union. 0148-0227/10/2009JC005517
}

Although most studies evidenced that these coefficients tend to be nonlinearly related to Chl [e.g., Mitchell and Kiefer, 1988; Cleveland, 1995; Bricaud et al., 1998; Lee et al., 1998; Sathyendranath et al., 2001], there has been no general agreement between the various parameterizations [Bricaud, 2002]. This suggests that, besides possible methodological differences between the various studies, the $a_{p}$ or $a_{\phi}$ versus $\mathrm{Chl}$ relationships might exhibit some regional and/or seasonal variations.

[3] The variability of absorption by NAPs, $a_{\mathrm{NAP}}(\lambda)$, has been less systematically investigated. Some studies suggested that the ratio $a_{\mathrm{NAP}} / a_{p}$ was not covarying with Chl [Cleveland, 1995; Bricaud et al., 1998], while being very variable from one oceanic region to the other, for example, between highand midlatitude waters [Sosik et al., 1992]. This ratio was found to be particularly low (around 10\% or less near the surface, instead of $25-30 \%$ on average) in the subequatorial region of the South Pacific [Bricaud et al., 1998] and in the western equatorial Pacific [Parslow et al., 1998].

[4] In contrast to particulate and algal absorption, there have been very few studies dealing with the spectral absorption coefficients of colored dissolved organic matter 
(CDOM) in the visible domain and their variability in the open ocean. Although CDOM, which in the open ocean originates only from degradation of phytoplankton, is known to be in low concentration in those waters, its effect on the bulk optical properties of seawater has long been recognized [Prieur and Sathyendranath, 1981; Bricaud et al., 1981]. CDOM measurements in oceanic waters remained scarce for a long time, however, because the classical spectrophotometric techniques (with an optical path length limited to $0.1 \mathrm{~m}$ ) are generally not sensitive enough for such measurements. Routine measurements became possible about 15 years ago, with the availability of in situ spectral or hyperspectral absorption meters (with $25 \mathrm{~cm}$ path length) equipped with filters. Simultaneous CDOM and particulate absorption measurements were performed with this technique, for example, in the equatorial Pacific, and confirmed the significant contribution of CDOM to the bulk optical properties of those waters [Pegau, 1996; Parslow et al., 1998; Simeon et al., 2003]. During the past decade, measurements on filtered samples also became accessible, with the development of liquid capillary waveguides with path lengths up to $2 \mathrm{~m}$, allowing very low absorption coefficients to be measured [D'Sa et al., 1999; Miller et al., 2002]. Until now, however, few extensive analyses of the distribution of CDOM in the open ocean based on in situ measurements have been performed, and the possible relationships linking CDOM to algal biomass and other parameters remain poorly documented. It results that the parameterization of CDOM absorption in bio-optical models is still highly uncertain.

[5] Recently, estimates of "colored detrital matter" (CDM, which includes both CDOM and NAPs, CDOM being generally predominant) based on ocean color analyses have emerged, using various approaches [Maritorena et al., 2002; Ciotti and Bricaud, 2006; Brown et al., 2008; Morel and Gentili, 2009]. These estimates have challenged the traditional view of CDOM as a relatively minor and stable component in the open ocean and have evidenced its dynamics at a global scale, thus confirming some in situ studies, such as that performed in the Sargasso Sea by Nelson et al. [1998]. However, most approaches remain to be validated on a larger scale with in situ measurements. Siegel et al. [2002] conducted the only study where an extensive comparison was made between satellite estimates and ocean optics databases. This study revealed a general agreement (i.e., no systematic bias) but a rather large scatter, confirming the need for in situ measurements to determine the spatial distribution of CDOM at a regional scale.

[6] The Biogeochemistry and Optics South Pacific Experiment (BIOSOPE) cruise (October-December 2004) in the southeast Pacific, which took place over an $8000 \mathrm{~km}$ transect from the Marquesas Islands to Concepcion (Chile), investigated a large range of oceanic regimes, from the hyperoligotrophic waters of the South Pacific Gyre (SPG) to the eutrophic waters in the upwelling area off Chile. This was a unique opportunity to investigate the spatial variations of the various components responsible for light absorption, along with numerous other optical, biological, and biogeochemical parameters, over a large variety of trophic conditions [see Claustre et al., 2008, and references therein]. In particular, the SPG, the most oligotrophic area of the world ocean according to Sea-viewing Wide Field-of-view Sensor (SeaWiFS) data, was at the time of the cruise a still unexplored region, with "extreme" values expected for all parameters including optical coefficients [Claustre and Maritorena, 2003].

[7] The aims of this paper are (1) to describe the spatial variations of the absorption coefficients of the various components (phytoplankton, NAPs, CDOM), and of their relative contributions to total absorption, over the variety of trophic conditions encountered during the transect; (2) to investigate the relationships linking these coefficients to algal biomass and other optical parameters; and (3) to identify any specificity in the optical properties of South Pacific waters with regard to other areas of the world ocean.

\section{Materials and Methods}

\subsection{Study Area and Sampling}

[8] Samples were collected during the BIOSOPE (BIOgeochemistry and Optics South Pacific Experiment) cruise which took place from October 26 to December 11, 2004 in South Pacific waters (Figure 1). The transect covered during this cruise crossed waters with very contrasted trophic conditions, from the mesotrophic waters around the Marquesas archipelago, to the very oligotrophic waters of the SPG, and to the eutrophic waters of the coastal upwelling near Chile. Along this transect, 21 short (8-h) and 6 long (2-5 days) stations were occupied (see locations in Figure 1). The long stations were located in the following areas: near the Marquesas Islands (MAR), in the high-nutrient and lowchlorophyll area east of the islands (HNL), in the center and at the eastern limit of the SPG (GYR and EGY, respectively), and in the upwelling area (UPW and UPX, 112 and $29 \mathrm{~km}$ from the coast, respectively). Water samples were collected at 10 depths, twice a day (around 0900 and 1200), using $12 \mathrm{~L}$ Niskin bottles mounted on a conductivity-temperature-depth (CTD) rosette system, for pigment analyses and particulate and CDOM absorption measurements.

\subsection{Pigment Analyses}

[9] For pigment analyses, seawater samples (with volumes ranging from $1 \mathrm{~L}$ in the upwelling area to $5.6 \mathrm{~L}$ in the $\mathrm{SPG}$ ) were filtered through $25 \mathrm{~mm}$ Whatman $\mathrm{GF} / \mathrm{F}$ glass-fiber filters. Filters were immediately frozen in liquid nitrogen and stored at $-80^{\circ} \mathrm{C}$ until analysis in the laboratory. Highperformance liquid chromatography (HPLC) measurements were performed, and 25 pigments were quantified, using a modified version of the method developed by Van Heukelem and Thomas [2001], as described by Ras et al. [2008]. The HPLC method was improved to be able to accurately quantify pigments over the large range of trophic levels encountered, especially in strongly oligotrophic conditions. Hereafter, the term Tchl $a$ stands for the total chlorophyll $a$ concentration (defined similarly by Ras et al. [2008] as the sum of chlorophyll $a$, including allomers and epimers, divinylchlorophyll $a$, chlorophyllide $a$, and chlorophyllide $a$-like pigments). The term Pheo $a$ includes the sum of pheophytin $a$, phaeophorbide $a$, and phaeophorbide $a$-like pigments. The measurement accuracy, as determined during intercomparison exercises [Hooker et al., 2009], is 7\% for Tchl $a$ and $21 \%$ on average for other pigments. For the clearest waters (for which the filtered volume was equal to $5.6 \mathrm{~L}$ ), the limits of detection (corresponding to a signal-to-noise ratio of 3 ) were $<0.0004 \mathrm{mg} \mathrm{m}^{-3}$ for all pigments, for example, $0.0001 \mathrm{mg} \mathrm{m}^{-3}$ 


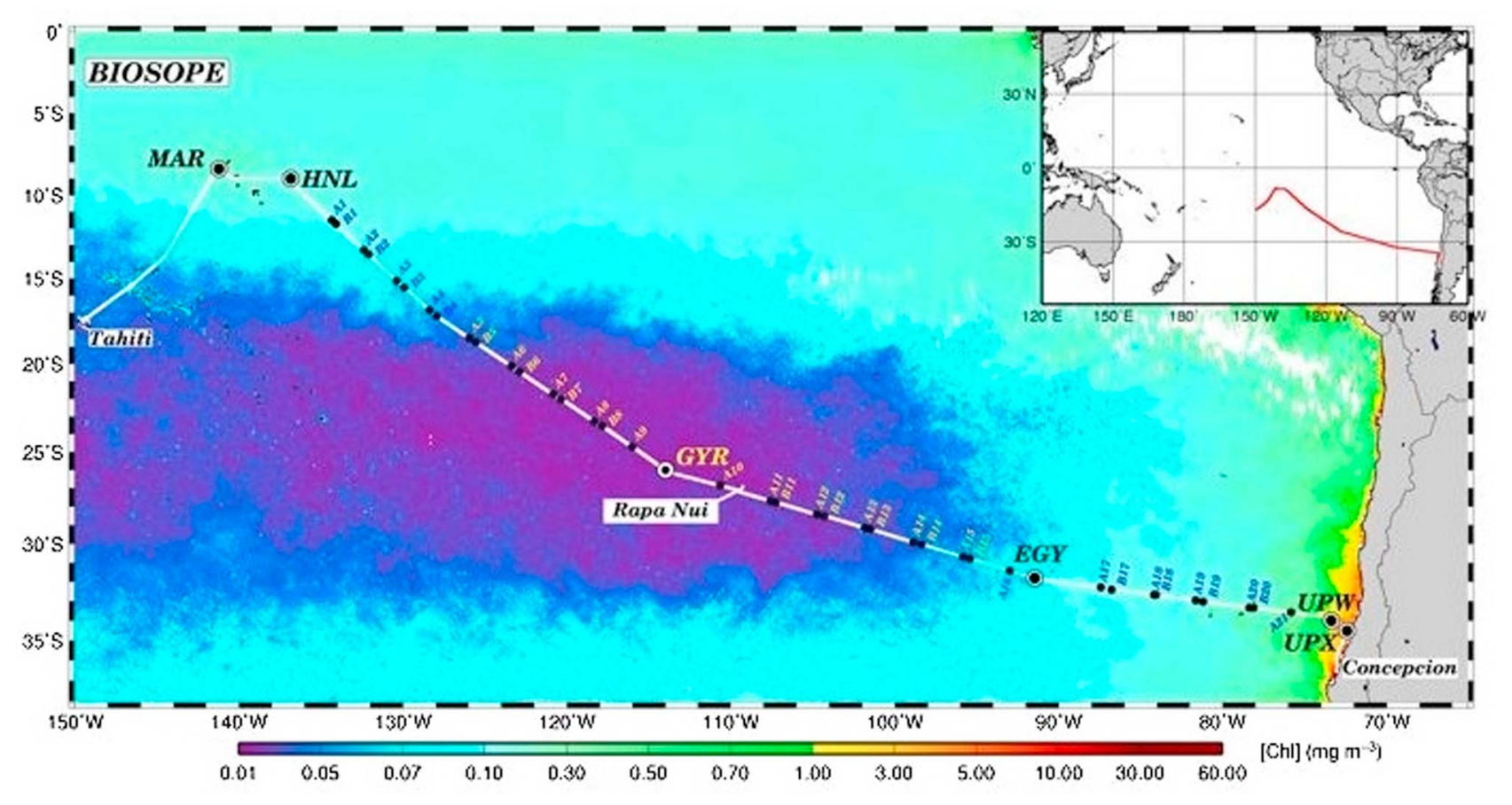

Figure 1. Transect followed by the BIOSOPE cruise, superimposed on a SeaWiFS composite image of chlorophyll $a$ concentration (first optical depth) for November-December 2004. After Claustre et al. [2008].

for Tchl $a$ and Tchl $b ; 0.0002 \mathrm{mg} \mathrm{m}^{-3}$ for fucoxanthin, peridinin, $19^{\prime}-\mathrm{HF}$, and $19^{\prime}$-BF; and $0.0003 \mathrm{mg} \mathrm{m}^{-3}$ for zeaxanthin and alloxanthin. These detection levels allowed a precise quantification of the various pigments to be performed even in the hyperoligotrophic waters of the SPG.

[10] Using these pigment determinations, the relative biomass proportions of pico- $(<2 \mu \mathrm{m})$, nano- $(2-20 \mu \mathrm{m})$, and microphytoplankton $(20-200 \mu \mathrm{m})$ were estimated, for each sample, from the concentrations of some pigments that are considered biomarkers of phytoplankton groups and associated to size classes [Vidussi et al., 2001]. The biomass proportions associated with each size class were computed from pigment ratios as described by Uitz et al. [2006]. The equations used for estimating these relative contributions were derived using a database of 2419 pigment profiles collected all over the world ocean. Note also that the accuracy of pigment ratios is increased compared to individual pigments, because some errors (e.g., errors on the sampling volume), which affect all pigment concentrations in a similar way, are canceled [Claustre et al., 2004]. From the relative proportions of phytoplankton size classes, a size index, representing a rough indicator of the dominant size of the algal population, was derived as described by Bricaud et al. [2004, equation (2)].

[11] The depth of the euphotic zone (Ze), that is, the depth where irradiance is reduced to $1 \%$ of its value just below the surface, was either measured or computed from the measured Tchl $a$ profiles using an iterative procedure described by Morel and Berthon [1989]. The first optical depth is equal to $Z e / 4.6$.

\subsection{Particulate Absorption Measurements}

[12] For particulate absorption measurements, seawater samples (with volumes varying from $1 \mathrm{~L}$ in the upwelling area to $11.2 \mathrm{~L}$ in the gyre) were collected on Whatman GF/F filters, and absorption spectra were measured directly on filters, with a Perkin-Elmer Lambda-19 spectrophotometer equipped with an integrating sphere, using a blank wet filter as a reference. Spectra were acquired between 300 and $800 \mathrm{~nm}$ with a $1 \mathrm{~nm}$ step. All spectra were shifted to zero in the near infrared by subtracting the average optical density between 750 and $800 \mathrm{~nm}$, so as to minimize possible differences between sample and reference filters. Optical densities were then corrected for the path-length amplification effect, using the algorithms developed (using measurements in the subequatorial Pacific) by Allali et al. [1997] for oligotrophic and mesotrophic waters and by Bricaud and Stramski [1990] for eutrophic waters (i.e., stations UPW and UPX). Optical densities were finally converted into particulate absorption $\left(a_{p}\right)$ coefficients (in $\mathrm{m}^{-1}$ ). Considering the possible variability of the $\beta$ factor (partly accounted for in this study), the accuracy of the $a_{p}$ coefficients is estimated to be about $15 \%$, while their precision (estimated on replicate samples) is a few percent in the visible domain (but larger in the UV domain, because of the sensitivity of mycosporine amino acids (MAAs) to the filtration process; see section 3.2.2). Note also that the filtered volume was adjusted so that even in the clearest waters the optical densities remained well above the detection limit of the spectrophotometer (e.g., an absorption coefficient of $0.001 \mathrm{~m}^{-1}$ corresponded to an optical density of 0.04$)$.

[13] The respective contributions of phytoplankton and NAPs to total particulate absorption were determined experimentally by extracting pigments in methanol [Kishino et al., 1985]. In spite of the long extraction time (up to 2 days), residual absorption by pigments was still present on numerous samples. To correct for this effect, NAP absorption coefficients were determined by applying a nonlinear, least- 
squares fit to the actual spectra, according to an exponential function,

$$
a_{\mathrm{NAP}}(\lambda)=a_{\mathrm{NAP}}\left(\lambda_{0}\right) \exp \left[-S_{\mathrm{NAP}}\left(\lambda-\lambda_{0}\right)\right]
$$

in the 300-380, 520-640, and 700-750 $\mathrm{nm}$ ranges, where the residual absorption by pigments can be assumed to be negligible. The wavelength $\lambda_{0}$ is a reference wavelength, and its choice has no impact on the value of $S_{\mathrm{NAP}}$. The fit was performed on raw (i.e., not log-transformed) data.

[14] Similarly to $a_{p}$ spectra, $a_{\mathrm{NAP}}$ spectra were then shifted to zero in the infrared, by subtracting the average optical density between 750 and $800 \mathrm{~nm}$. Then, for each sample, the spectral values of $a_{\phi}(\lambda)$ were obtained by subtracting $a_{\text {NAP }}(\lambda)$ from $a_{p}(\lambda)$, and Chl-specific values of phytoplanktonic absorption, denoted $a_{\phi}{ }^{*}(\lambda)$, were computed by dividing $a_{\phi}(\lambda)$ by the $[$ Tchl $a+$ Pheo $a]$ concentration.

\subsection{CDOM Absorption Measurements}

[15] CDOM absorption measurements were performed using a multiple path length, liquid core waveguide (Ultrapath, WPI Inc., Sarasota, FL, USA). The Ultrapath system is a spectrophotometer that includes a waveguide with a userselectable path length $(2,10,50$, and $200 \mathrm{~cm})$. Water samples are injected into the cell using a peristaltic pump. Incident light provided by deuterium and tungsten sources reaches the sample cell via an optical fiber and travels by internal reflection within the waveguide. Light exiting the waveguide is collected by another optical fiber connected to a photodiode array. The instrument (UP-UV version) operates in the 250 $730 \mathrm{~nm}$ range with a resolution of $5 \mathrm{~nm}$. The system is specified to have a dynamic range of 0.002 to $231 \mathrm{~m}^{-1}$, with a maximum deviation in replicate spectra $<0.001$ absorbance units [Miller et al., 2002]. Samples were prefiltered on a $200 \mu \mathrm{m}$ mesh and then filtered under dim light into glass bottles, using $0.2 \mu \mathrm{m}$ Sartorius filter units previously rinsed with at least $250 \mathrm{~mL}$ of Milli-Q water. They were then immediately analyzed on board, starting with surface samples to let deeper samples reach the temperature of reference water. This minimized temperature effects on absorption spectra, which result from the temperature dependence of the absorption coefficients of pure water and are mostly visible in the infrared [Pegau et al., 1997]. Reference water was HPLCquality water, artificially salted $\left(35 \mathrm{~g} \mathrm{~L}^{-1}\right)$, with precombusted salt to remove possible organic contamination. This minimizes the differences in refractive index between sample and reference, which can induce offsets in absorption [ $D^{\prime} \mathrm{Sa}$ et al., 1999]. Between measurements, the sample cell was carefully flushed successively with diluted solutions of detergent, high-reagent-grade $\mathrm{MeOH}, \mathrm{HCl}$, and Milli-Q water. The cleanliness of the cell, highly critical for the quality of measurements, was checked by controlling the stability of the transmittance of reference water. Care was also taken to avoid the presence of bubbles, which is also crucial for the quality of measurements. Their presence can be easily detected by nonzero absorption values in the near-infrared part of the spectrum. When they could not be eliminated, the corresponding measurements were discarded. Multiple measurements (including all handling and filtration steps) on one water sample showed that the reproducibility of measurements was approximately $\pm 0.005 \mathrm{~m}^{-1}$ at $375 \mathrm{~nm}$.
[16] Finally, the measured absorbance values were converted into absorption coefficients, $a_{\mathrm{CDOM}}(\lambda)$ (in $\mathrm{m}^{-1}$ ). For each spectrum, the spectral slope, $S_{\mathrm{CDOM}}$ (in $\mathrm{nm}^{-1}$ ), was computed by applying a nonlinear, least-squares fit to the $a_{\mathrm{CDOM}}(\lambda)$ values between 350 and $500 \mathrm{~nm}$. The fit was performed on raw (i.e., not log-transformed) data, according to the recommendations of Twardowski et al. [2004].

\section{Results and Discussion}

[17] Hydrographic conditions encountered along the transect have been described in detail by Claustre et al. [2008]. In summary, they distinguished five main areas with different temperature, salinity, and density properties, associated with different water masses (Figure 2): (1) the subequatorial area $\left(142^{\circ} \mathrm{W}-132^{\circ} \mathrm{W}\right)$, under the influence of the South Equatorial Current, with low-salinity (35.6) and warm $\left(>27.5^{\circ}\right)$ waters; (2) the transition zone between the subequatorial area and the SPG $\left(132^{\circ} \mathrm{W}-123^{\circ} \mathrm{W}\right)$, corresponding to the South Tropical Surface Water, less warm (around $25^{\circ}$ ) and saltier (around 36.5) than the subequatorial waters; (3) the central part of the SPG $\left(123^{\circ} \mathrm{W}-101^{\circ} \mathrm{W}\right)$, corresponding to the strongly stratified Eastern South Pacific Central Water (ESPCW) and spanning a wide temperature and salinity range (the strong salinity gradient around $100^{\circ} \mathrm{W}$ corresponds to the northern limit of the Subtropical Front); (4) the zone between the SPG and the coastal upwelling area $\left(100^{\circ} \mathrm{W}-\right.$ $81^{\circ} \mathrm{W}$ ), corresponding to the transition between ESPCW and the fresher Subantarctic Surface Water [SASW; note also the tongue of low-salinity waters, which corresponds to the source of Eastern South Pacific Intermediate Water (ESPIW)]; and (5) the coastal upwelling area (east of $81^{\circ} \mathrm{W}$ ), where the ESPIW lies above the Equatorial Subsurface Water, which is characterized by higher salinity $(>34.5)$ and is part of the Peru-Chile Undercurrent. The distribution of these water masses rules the spatial distributions of temperature and salinity, which, in turn, influence those of algal populations and associated optical properties.

\subsection{Spatial Distribution of Algal Biomass and Phytoplankton Size Classes}

[18] A large diversity of waters was encountered during the cruise, with Tchl $a$ concentrations spanning more than two orders of magnitude ( 0.017 to $\left.1.5 \mathrm{mg} \mathrm{m}^{-3}\right)$ in the surface layer. The spatial distribution of Tchl $a$ concentrations has been (along with other pigments) described in detail by Ras et al. [2008] and is briefly summarized hereafter (see also Figure 3a). The area around the Marquesas Islands (stations MAR and HLN) was mesotrophic, with nitrate concentrations exceeding $1 \mu \mathrm{mol} \mathrm{L}^{-1}$ in the surface layer [Raimbault et al., 2008] and surface Tchl $a$ concentrations in the range $0.2-$ $0.4 \mathrm{mg} \mathrm{m}{ }^{-3}$. The surface Tchl $a$ concentrations were the lowest in the center of the SPG (around the GYR station), reaching values as low as $0.017 \mathrm{mg} \mathrm{m}^{-3}$ at station 6 . The upper $100 \mathrm{~m}$ layer of the whole SPG area was found to be nutrient depleted (with nitrate concentrations sometimes undetectable and always $<0.010 \mu \mathrm{mol} \mathrm{L}^{-1}$ ) [Raimbault et al., 2008]. East of the SPG, Tchl $a$ concentrations increased progressively toward the Chilean upwelling area (stations UPW and UPX), where they reached values up to $1.5 \mathrm{mg} \mathrm{m}^{-3}$, while surface nitrate concentrations exceeded $5 \mu \mathrm{mol} \mathrm{L}^{-1}$ east of $76^{\circ} \mathrm{W}$, the western limit of the upwelling [Raimbault et al., 

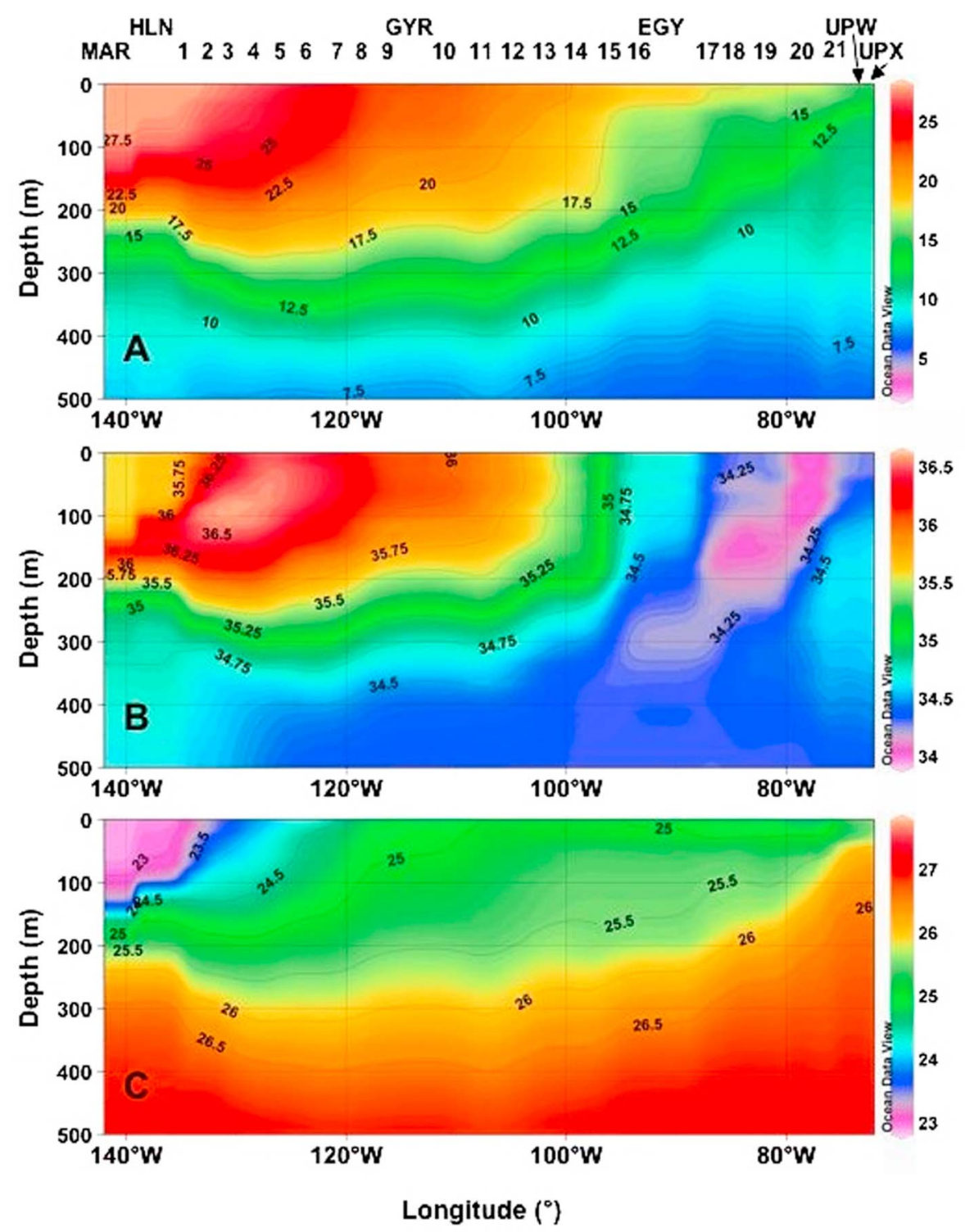

Figure 2. Contour plots of (a) potential temperature (in ${ }^{\circ} \mathrm{C}$ ), (b) salinity, and (c) potential density (in $\mathrm{kg} \mathrm{m}^{-3}$ ) for the cruise transect. Color scales are indicated on the right (Ocean Data View software, version 3.4.2, R. Schlitzer, http://odv.awi.de/, 2008). After Claustre et al. [2008].

2008]. Chlorophyllide $a$ and pheopigments were scarce (0$1 \%$ of Tchl $a$ ) in the SPG, present in variable amounts in the mesotrophic area (around MAR and HNL stations), and present in high concentrations (up to $27 \%$ of Tchl $a$ ) in the upwelling area.

[19] The DCM, with Tchl $a$ values approximately tenfold higher than at the surface, was found to migrate progressively from $50 \mathrm{~m}$ around the Marquesas Islands to $190 \mathrm{~m}$ at station 6 and $180 \mathrm{~m}$ in the center of the SPG, and then to move again toward the surface when approaching the Chilean upwelling area, where the water column was homogeneous down to approximately $50 \mathrm{~m}$. The depth of the euphotic layer followed the DCM throughout the transect, except in the center of the SPG where it was located just above the DCM (Figure 3a).

[20] The relative contributions of phytoplankton size classes to total algal biomass have also been described by Ras et al. [2008] (see Figure 3b). Briefly, in the mesotrophic waters around the Marquesas Islands, the dominant populations were nanophytoplankton (40-50\%), while the contributions of pico- and microphytoplankton to Tchl $a$ were similar near the surface (20-30\%) and approximately $40 \%$ and $10 \%$ below $100 \mathrm{~m}$, respectively. Within the euphotic layer of the SPG, although picophytoplankton were the dominant population (around 50\% of Tchl $a$ ), nanophytoplankton contributed $30-40 \%$ and microphytoplankton $10-20 \%$ of Tchl $a$. Note that the contribution of picophytoplankton was the highest $(>70 \%$ near the surface) in the formation area of South Pacific tropical waters (stations 2-5, between $132^{\circ} \mathrm{W}$ and $\left.125^{\circ} \mathrm{W}\right)$. In the upwelling area, the proportion of microphytoplankton increased markedly; at station UPX, it contributed to the Tchl $a$ concentration for more than $60 \%$, while pico- and nanophytoplankton each contributed approximately $20 \%$ near the surface and $10 \%$ at depth. The spatial distribution of the individual pigments contributing 

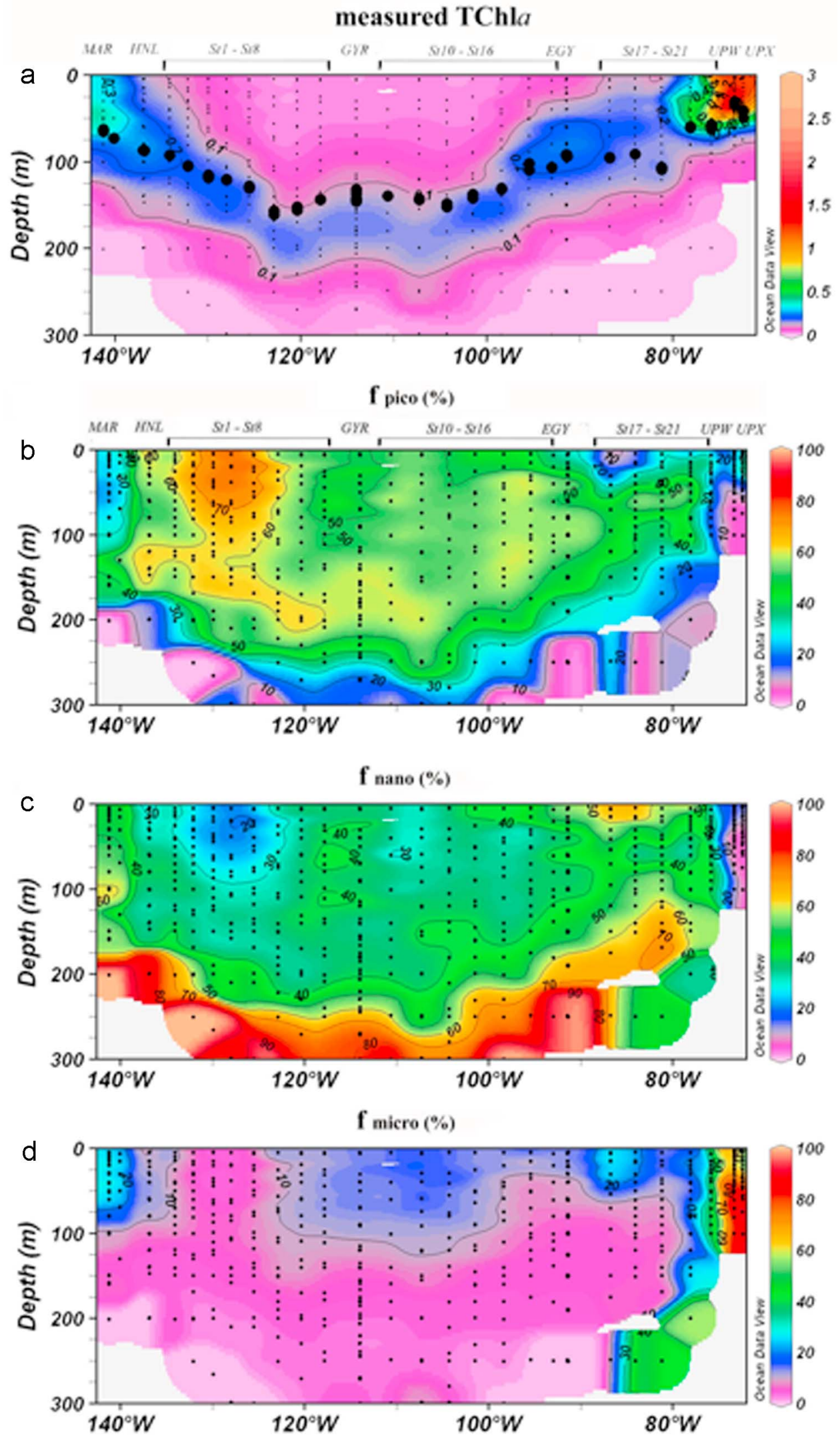

Figure 3. (a) Contour plot of the measured Tchl $a$ concentrations (in $\mathrm{mg} \mathrm{m}^{-3}$ ) for the cruise transect. Black dots represent the euphotic depth. Small dots represent samples collected at each station. (b) Contour plots of the relative contributions of picophytoplankton $\left(f_{\text {pico }}\right)$, nanophytoplankton $\left(f_{\text {nano }}\right)$, and microphytoplankton $\left(f_{\text {micro }}\right)$ to total biomass (in \%), computed according to Uitz et al. [2006]. After Ras et al. [2008]. 


\section{$\mathbf{a}_{\psi}(440)$}
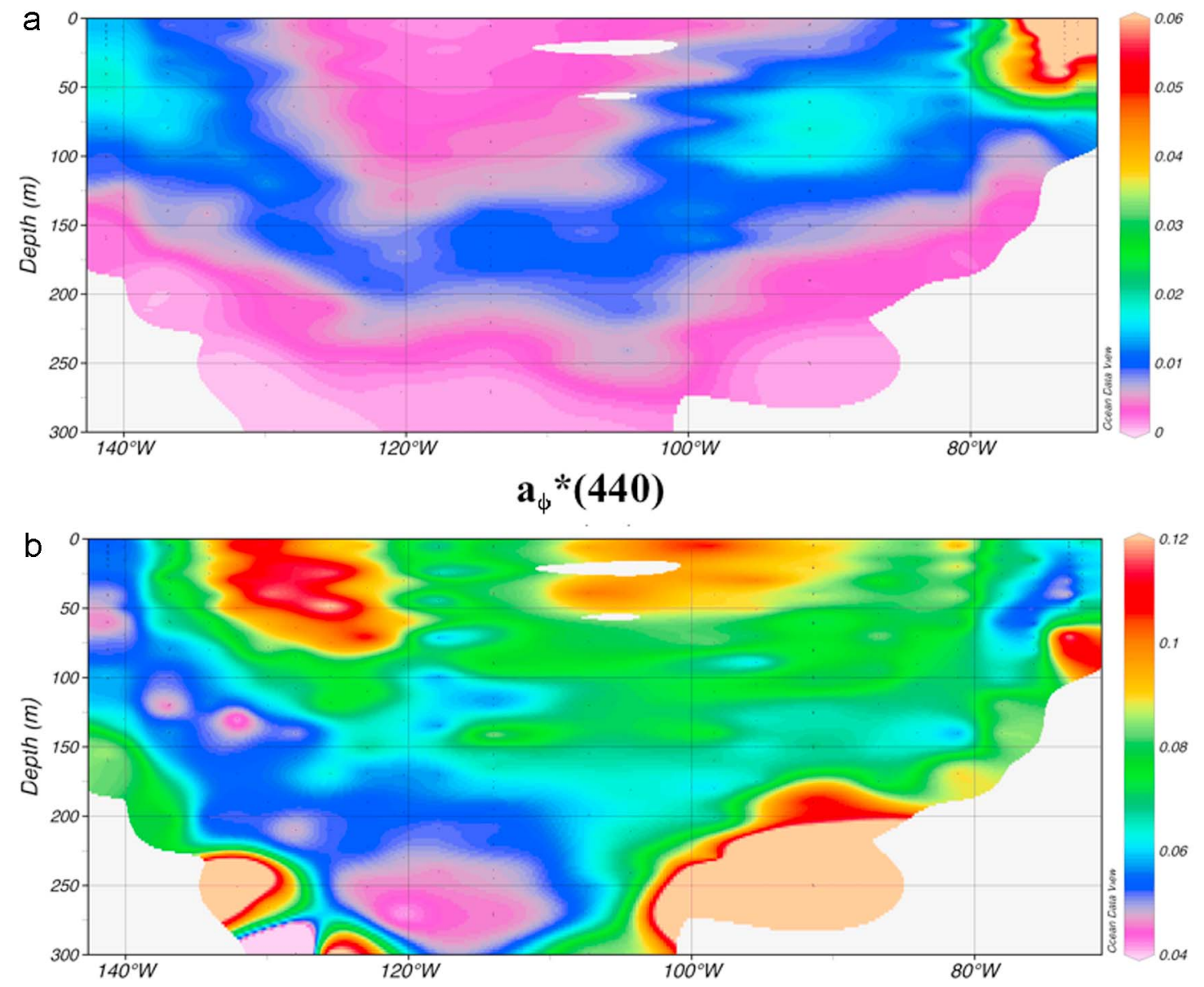

Figure 4. Contour plots of (a) the absorption coefficient of phytoplankton at $440 \mathrm{~nm}, a_{\phi}(440)\left(\right.$ in $\left.\mathrm{m}^{-1}\right)$ and (b) the same coefficient normalized by the [Tchl $a+$ pheo $a$ ] concentration, $a_{\phi} *(440)\left(\right.$ in $\left.\mathrm{m}^{2} \mathrm{mg}^{-1}\right)$, for the cruise transect.

to each size class is rather complex, and a detailed description can be found in the work of Ras et al. [2008].

\subsection{Light Absorption by Phytoplankton}

\subsubsection{Variability of Phytoplanktonic Absorption in the Visible Domain}

[21] The contour plot of the absorption coefficient of phytoplankton at $440 \mathrm{~nm}, a_{\phi}(440)$, reveals a variation range covering two orders of magnitude $\left(0.0008-0.08 \mathrm{~m}^{-1}\right)$ throughout the transect and, not surprisingly, spatial variations very similar to those of Tchl $a$ (Figure 4a). In spite of this similarity [which suggests a strong covariation between $a_{\phi}$ (440) and the Tchl $a$ concentration], $a_{\phi} *(440)$ is far from being constant (Figure 4b). High values $\left(>0.07 \mathrm{~m}^{2} \mathrm{mg}^{-1}\right)$ are observed near the surface in the whole area where the Tchl $a$ concentration is $<0.1 \mathrm{mg} \mathrm{m}^{-3}$, from station HNL to station 17 (approximately $137^{\circ} \mathrm{W}$ to $87^{\circ} \mathrm{W}$ ). Such high values indicate a low packaging effect and/or high concentrations of nonphotosynthetic pigments, which is consistent with the abundance of picophytoplankton in this area (see Figure $3 \mathrm{~b}$ ). In the surface layer, the highest values of $a_{\phi} *(440)\left(>0.1 \mathrm{~m}^{2} \mathrm{mg}^{-1}\right)$ are observed between stations 2 and $5\left(132^{\circ} \mathrm{W}-125^{\circ} \mathrm{W}\right)$, which is also the area where the contribution of picoplankton to the total algal biomass is the highest $(>70 \%)$. Note, however, that values $>0.1 \mathrm{~m}^{2} \mathrm{mg}^{-1}$ are also found between $105^{\circ} \mathrm{W}$ and $95^{\circ} \mathrm{W}$ (stations $12-15$ ), an area that does not correspond to a maximum in picoplankton abundance. The lowest values $\left(<0.05 \mathrm{~m}^{2} \mathrm{mg}^{-1}\right)$ are observed in the eutrophic upwelling area, where the contribution of microphytoplankton to total algal biomass exceeds $60 \%$ and the packaging effect is expected to be high. Intermediate values $(0.05-$ $\left.0.075 \mathrm{~m}^{2} \mathrm{mg}^{-1}\right)$ are found in the mesotrophic waters around the MAR station.

[22] Within the SPG, $a_{\phi} *(440)$ tends to decrease along the vertical. This does not likely result from a change in populations (the contributions of pico- and nanophytoplankton to total algal biomass show weak vertical variations; see Figure $3 \mathrm{~b}$ ), but from photoacclimation of cells to lower light levels (inducing a higher packaging effect, along with a decrease in the zeaxanthin/Tchl a ratio; see Ras et al. [2008]). In the mesotrophic and eutrophic areas, $a_{\phi} *(440)$ does not show such a regular trend.

[23] Examples of Chl-specific phytoplanktonic absorption spectra, for three stations (MAR, GYR, and UPW) repre- 


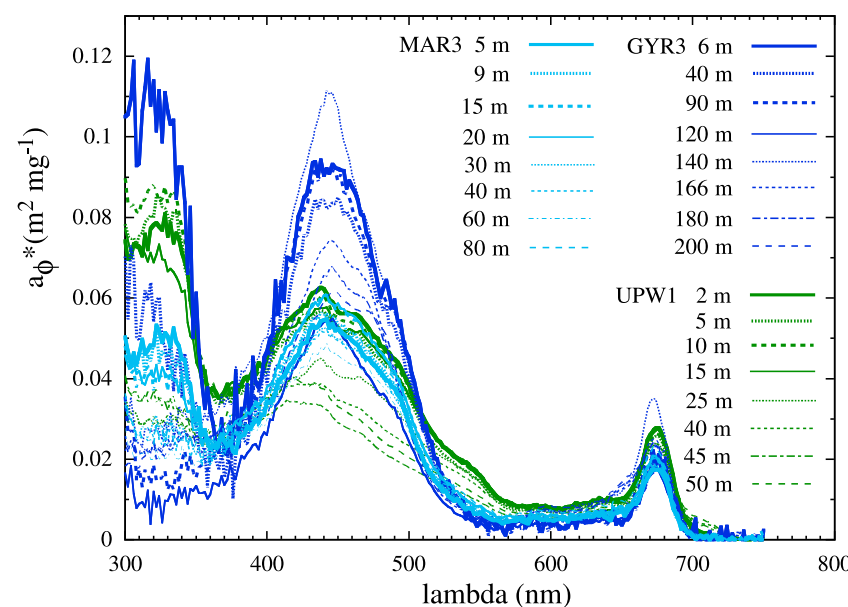

Figure 5. Examples of Chl-specific phytoplanktonic absorption spectra measured at three stations: the mesotrophic station MAR (day 3), the hyperoligotrophic station GYR (day 3), and the upwelling station UPW (day 1) (see Figure 1 for the location of stations).

senting the typical regimes encountered during the transect and for various depths, are shown in Figure 5. The features just described for the three stations can also be observed: the $a_{\phi}{ }^{*}$ coefficients are the highest at the hyperoligotrophic station GYR $\left(0.095 \mathrm{~m}^{2} \mathrm{mg}^{-1}\right.$ at $440 \mathrm{~nm}$ near the surface $)$ and are significantly lower for mesotrophic waters $\left(0.055 \mathrm{~m}^{2} \mathrm{mg}^{-1}\right.$ at the MAR station) and eutrophic waters $\left(0.043 \mathrm{~m}^{2} \mathrm{mg}^{-1}\right.$ at the UPW station). Also, the $a_{\phi}{ }^{*}$ values decrease notably (by about a factor of 2 at $440 \mathrm{~nm}$ ) with increasing depth at the GYR station, whereas they are relatively homogeneous within the $0-50 \mathrm{~m}$ layer at the UPW station and down to $100 \mathrm{~m}$ at the MAR station. Note also that absorption spectra measured in the surface layer at all sites reveal bumps around $320 \mathrm{~nm}$ originating from the presence of MAAs.

[24] Our previous studies for various waters [Bricaud et al., 1995, 2004] and for the subequatorial Pacific [Allali et al., 1997] already evidenced that the $a_{\phi}$ coefficients tend to increase (and the $a_{\phi}{ }^{*}$ coefficients tend to decrease) nonlinearly with increasing Tchl $a$ values as a result of both a decreasing contribution of nonphotosynthetic pigments and increasing pigment packaging. This general trend is thus confirmed for the southeast Pacific waters, including for hyperoligotrophic waters, which were quasi-absent in the previous data sets (Figure 6). Note, however, that the $a_{\phi}(440)$ values observed for the southeast Pacific waters are (with the exception of the upwelling area) notably lower than those observed for other oceanic areas with a similar chlorophyll content. For instance, the $a_{\phi}$ (440) values measured in the surface layer (first optical depth) over the Tchl $a$ range $0.03-0.2 \mathrm{mg} \mathrm{m}^{-3}$ are $30 \%-50 \%$ lower than those measured in the Mediterranean, Atlantic, and subequatorial Pacific waters (Figure 6). The difference is still more striking for the waters in the center of the SPG (with Tchl $a$ concentrations around $0.02 \mathrm{mg} \mathrm{m}^{-3}$ ), where the $a_{\phi}(440)$ values (around $0.0015 \mathrm{~m}^{-1}$ ) are three times lower than in the Mediterranean $\left(0.004-0.005 \mathrm{~m}^{-1}\right)$. In the upwelling area, in contrast, the $a_{\phi}$ (440) values are close to those observed, for similar Tchl $a$ contents, in Atlantic waters (Mauritanian and Benguela upwelling areas). As a result, the relationship obtained by fitting a power function to the data from the BIOSOPE area (first optical depth),

$$
a_{\phi}(440)=0.0617 \operatorname{Tchl} a^{0.93}\left(r^{2}=0.97, N=66\right),
$$

is notably different from, and closer to linearity than, the average relationship derived by Bricaud et al. [2004]:

$$
a_{\phi}(440)=0.0654 \operatorname{Tchl} a^{0.73}\left(r^{2}=0.93, N=596\right) .
$$

Such low $a_{\phi}$ values can result from a lower contribution (compared to previous observations) of some accessory pigments to $a_{\phi}$ (440), from differences in the size structure of algal populations (a larger algal size induces a larger packaging effect and therefore lower $a_{\phi}$ coefficients [e.g., Morel and Bricaud, 1981]), or both. The variations in ratios of accessory pigments to Tchl $a$ with Tchl $a$ were examined independently for the four main groups of accessory pigments: (1) chlorophyll $b$ and divinyl $\mathrm{Chl} b$; (2) chlorophyll $c 1, c 2$, and $c 3$; (3) photosynthetic carotenoids (including fucoxanthin, peridinin, 19'-HF, and 19'-BF); and (4) nonphotosynthetic carotenoids (PPCs, including zeaxanthin, diadinoxanthin, alloxanthin, and $\beta$-carotene). For the first three groups, the ratios were not significantly lower than for other areas (not shown). The PPC/Tchl $a$ ratios were not different either, except for the most oligotrophic waters of the SPG (with TCHL $a<0.03 \mathrm{mg} \mathrm{m}^{-3}$ ), where values were higher than in the Mediterranean but notably lower than in the (less oligotrophic) subequatorial Pacific waters (Figure 7a).

[25] Considering the variations in the size index of algal populations with Tchl $a$ concentrations (Figure 7b), it can be observed that phytoplankton in the BIOSOPE area are in a

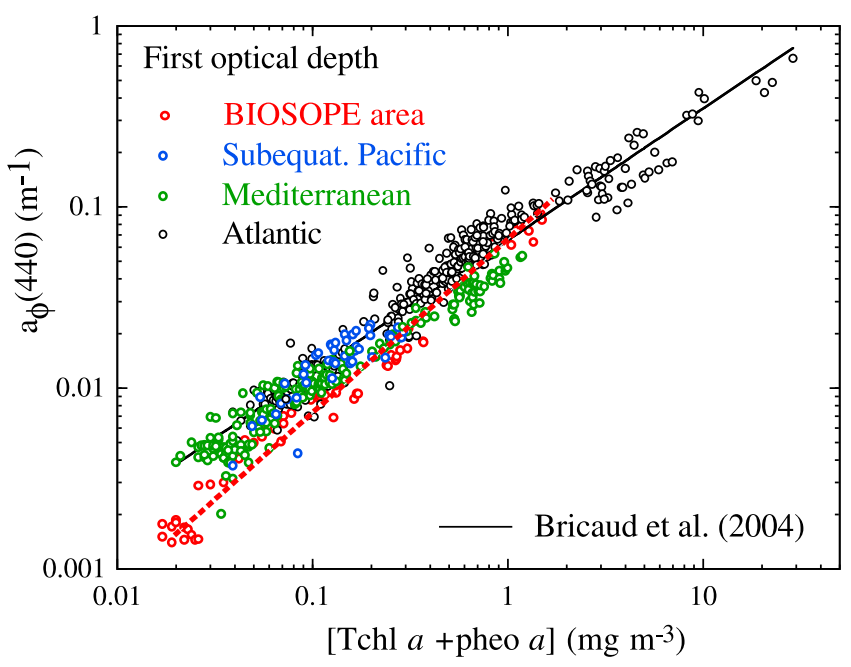

Figure 6. Variations of the absorption coefficients of phytoplankton at $440 \mathrm{~nm}$ as a function of the $[\mathrm{Tchl} a+$ pheo $a]$ concentration, for various areas. Data collected during cruises other than BIOSOPE are taken from the work of Bricaud et al. [2004]. The red and black lines are the regression lines corresponding to equations (1) (BIOSOPE area) and (2) [Bricaud et al., 2004], respectively. 

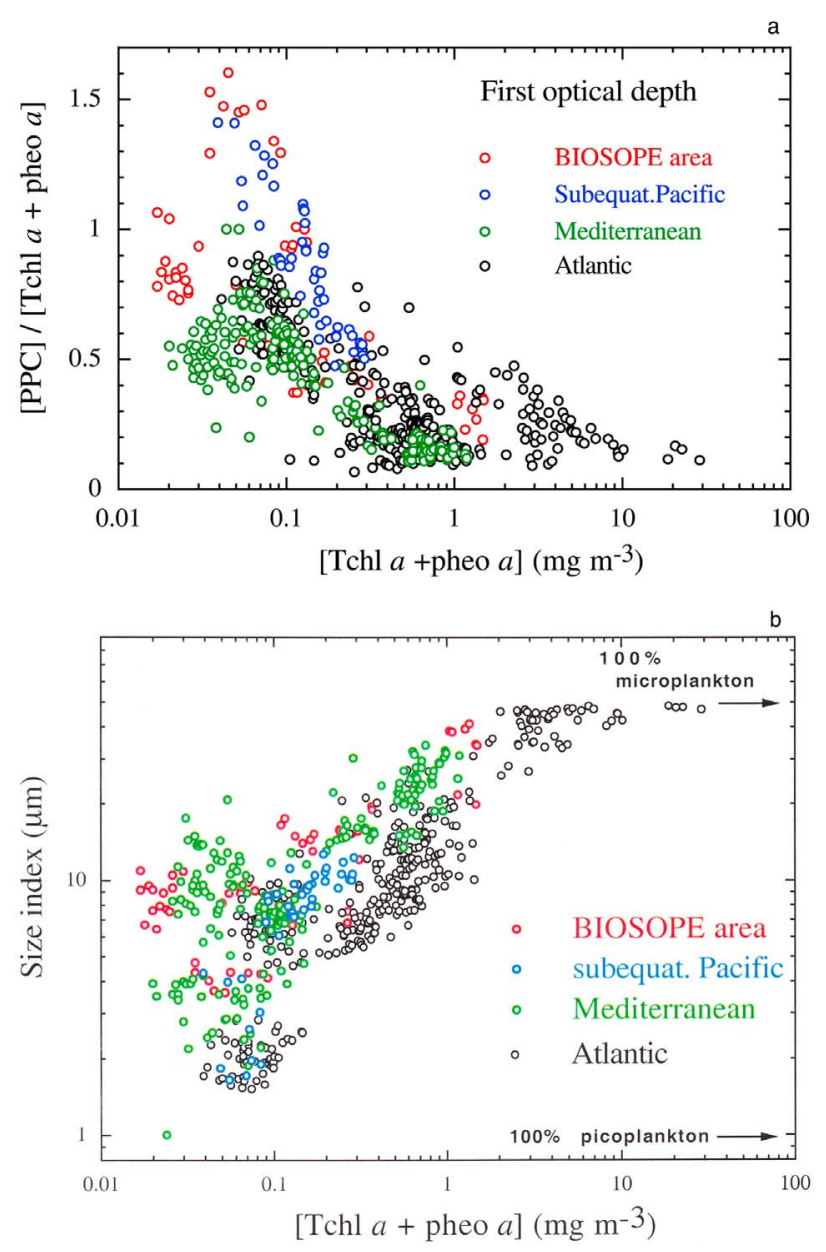

Figure 7. (a) Variations of the nonphotosynthetic pigmentsto- $[$ Tchl $a+$ pheo $a]$ ratios as a function of the [Tchl $a+$ pheo $a]$ concentration for various areas. Data collected during cruises other than BIOSOPE are taken from Bricaud et al. [2004]. Nonphotosynthetic pigments include zeaxanthin, diadinoxanthin, alloxanthin, and $\beta$-carotene. (b) Variations of the size index, estimated from the relative contributions of pico-, nano-, and microphytoplankton to total biomass [see Bricaud et al., 2004] as a function of the [Tchl $a+$ pheo $a$ ] concentration for various areas.

similar size range compared to other areas with similar Tchl $a$ contents, except in the clearest waters (Tchl $a<0.03 \mathrm{mg} \mathrm{m}^{-3}$ ), where the size index $(7-10 \mu \mathrm{m})$ is about three times higher than for Mediterranean waters $(1-4 \mu \mathrm{m})$.

[26] Therefore, differences in average algal size and nonphotosynthetic pigment contents both can account for the lower $a_{\phi}$ (440) coefficients observed in the SPG compared to other areas. These differences tend to blur in mesotrophic waters, and disappear in eutrophic waters, consistently with the behavior of $a_{\phi}$ (440) coefficients. Both the higher algal size and the lower PPC content (relatively to Tchl $a$ ) likely result from the significant contribution of nanophytoplankton to the total biomass in the oligotrophic waters within and around the gyre (Figure 3b). While nanophytoplanktonic species contributed to total biomass for about $40 \%$ in the SPG, they were in much lower quantity (if not absent) in the oligotrophic waters of other (subequatorial Pacific, Mediterranean, and Atlantic) areas, characterized by a predominance of picophytoplankton.

\subsubsection{Variability of Phytoplanktonic Absorption} in the UV Domain: Influence of MAAs

[27] Phytoplanktonic absorption spectra shown as examples in Figure 5 exhibit a high variability in the UV domain, with the bumps around $320 \mathrm{~nm}$ mostly apparent in the surface layer and decreasing in amplitude along the vertical. This suggests that the concentration of MAAs in algal cells is high in the surface layer and lower at depth. The variability of algal absorption in the UV domain, however, has to be considered cautiously when it is determined from filters. Laurion et al. [2003] demonstrated, on cultured species containing MAAs, that these can be released through the intact cell membranes during (or very shortly after) filtration, which induces an increase in absorption in the UV domain. They also observed (at least for dinoflagellates) that the amplitude of the UV peak varies with the time elapsed since filtration. Therefore, the observed variations are possibly subject to large uncertainties.

[28] These variations, however, appear to be spatially well structured. An index of the abundance of MAAs is the absorption ratio $a_{\phi}(320) / a_{\phi}$ (365). The contour plot of this ratio (Figure 8) shows that MAAs are abundant $\left[a_{\phi}(320) / a_{\phi}\right.$ $(365)>2]$ in the surface layer of the whole area, except around the HNL and UPX stations. The absorption ratio reaches 5 in the surface layer of the SPG and is higher than 3 down to approximately $50 \mathrm{~m}$. This abundance in the surface layer was expected because the production of MAAs to protect cells from UV radiation damage is a well-known mechanism [e.g., Dunlap and Schick, 1998]. A large diversity in the shape of UV absorption can be observed on algal absorption spectra (see examples in Figure 5). Some reveal a narrow peak around $310-320 \mathrm{~nm}$, indicating the presence of a dominant type of MAAs, which could be mycosporineglycine or palythine [Laurion et al., 2003], whereas other spectra reveal high UV absorption but no individualized peak, indicating the presence of a mixture of various MAAs. This suggests a compositional change of MAAs along the transect, which, however, does not appear clearly spatially structured.

\subsection{Light Absorption by Nonalgal Particles 3.3.1. Spatial Variations of Nonalgal Absorption} at $440 \mathrm{~nm}$

[29] The spatial variations of $a_{\mathrm{NAP}}(440)$ and of the chlspecific coefficient $a_{\mathrm{NAP}} *(440)$ are displayed in Figures $9 \mathrm{a}$ and $9 \mathrm{~b}$. As for $a_{\phi}(440)$, the $a_{\mathrm{NAP}}(440)$ coefficients globally covary with algal biomass, with low values $(0.0003-$ $\left.0.002 \mathrm{~m}^{-1}\right)$ in the oligotrophic area, large values $(>0.01$ $\mathrm{m}^{-1}$ ) in the upwelling area, and intermediate values in mesotrophic waters $\left(0.001-0.005 \mathrm{~m}^{-1}\right)$. The spatial patterns in $a_{\mathrm{NAP}}(440)$, however, show much less similarity with those of the Tchl $a$ concentration than $a_{\phi}$ (440), suggesting a large scatter in the $a_{\mathrm{NAP}}(440)$ versus Tchl $a$ relationship.

[30] The Chl-specific coefficients $a_{\mathrm{NAP}} *(440)$ exhibit large values $\left(0.02-0.05 \mathrm{~m}^{2} \mathrm{mg}^{-1}\right)$ within the surface layer in the center and around the gyre, while values remain $<0.02 \mathrm{~m}^{2} \mathrm{mg}^{-1}$ in mesotrophic and eutrophic waters and at depth [Figure 9b; high values below the DCM are likely artifactual, as $a_{\mathrm{NAP}}(440)$ and Tchl $a$ are both close to zero]. This indicates that the 


\section{$\mathbf{a}_{\phi}(\mathbf{3 2 0}) / \mathbf{a}_{\phi}(\mathbf{3 7 0})$}

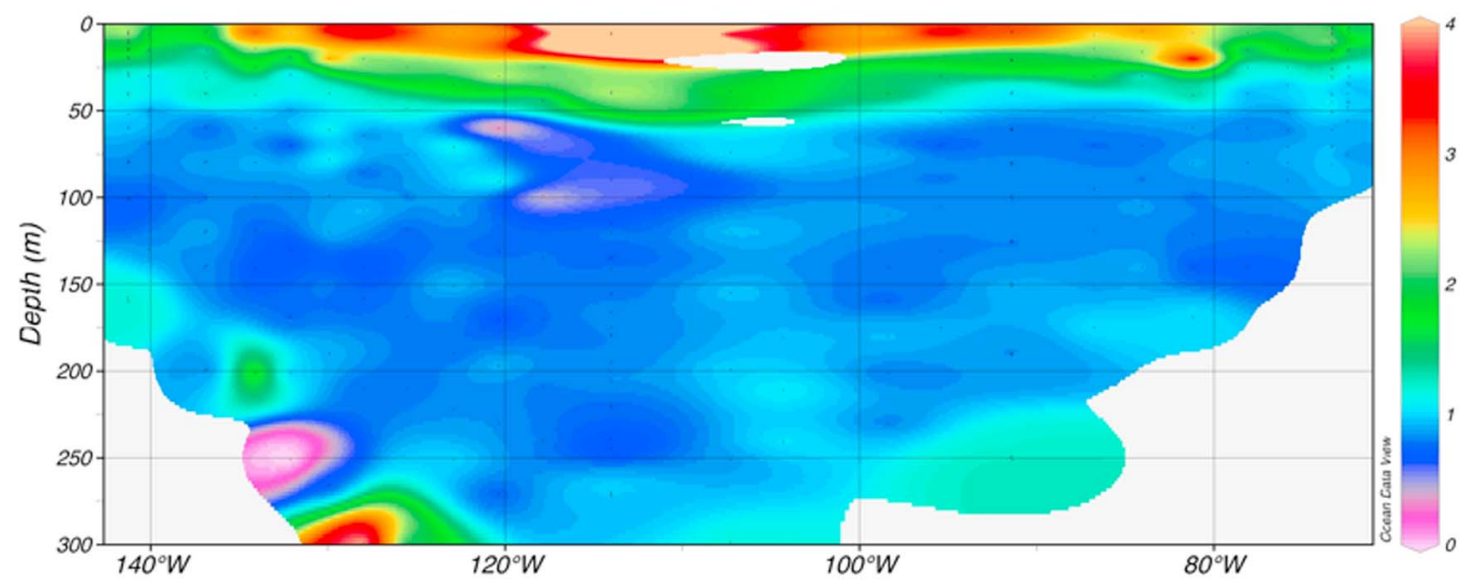

Figure 8. Contour plot of the absorption ratio $a_{\phi}(320) / a_{\phi}(370)$ for the cruise transect. This ratio is taken as an indicator of the abundance of mycosporine amino acids.

proportion of nonalgal particles to algal biomass is the highest in the surface layer of the gyre or, alternatively, that nonalgal particles are of a different nature (and more colored) than in other areas.

[31] Figure 10a demonstrates that the variations of $a_{\mathrm{NAP}}(440)$ are actually correlated with those of Tchl $a$ concentration, with however a large scatter, especially for waters with Tchl $a<0.5 \mathrm{mg} \mathrm{m}^{-3}$. If the analysis is restricted to the first optical depth, the trend remains similar (Figure 9b). It appears that, in the oligotrophic and mesotrophic waters of the BIOSOPE area (Tchl $a<0.5 \mathrm{mg} \mathrm{m}^{-3}$ ), the $a_{\mathrm{NAP}}(440)$ values are similar to those measured in subequatorial Pacific waters but lower than in the Mediterranean and Atlantic waters with similar Tchl $a$ concentrations. For eutrophic waters (Tchl $\left.a>1 \mathrm{mg} \mathrm{m}^{-3}\right)$, the $a_{\mathrm{NAP}}(440)$ values are similar to those measured in other areas of the world ocean. For the surface layer (limited to the first optical depth), the regression analysis provides the following relationships:

$$
a_{\mathrm{NAP}}(440)=0.0067 \text { Tchl } a^{0.675}\left(r^{2}=0.80\right)
$$

for the BIOSOPE area and

$$
a_{\mathrm{NAP}}(440)=0.0136 \mathrm{Tchl} a^{0.615}\left(r^{2}=0.71\right)
$$

when all samples are pooled together, evidencing that values for the BIOSOPE area are on average twofold lower than in other areas for a given Tchl $a$ content.

[32] Because both $a_{\phi}$ and $a_{\mathrm{NAP}}$ are lower than in other areas with similar Tchl $a$ contents, it results that this is also the case for the particulate absorption coefficient, $a_{p}$. It is interesting to check whether the nonalgal-to-particulate-absorption ratio $a_{\mathrm{NAP}} / a_{p}$ differs from other areas. As shown in Figure 11, the $a_{\mathrm{NAP}}(440) / a_{p}(440)$ ratios are significantly different from those observed in other regions (see legend of Figure 11). They are on average lower than those measured in the Mediterranean and Atlantic waters but remain larger than the (extremely low) values measured in the subequatorial Pacific. This suggests that in southeast Pacific waters not only the amplitude of $a_{\phi}$ and $a_{\mathrm{NAP}}$ coefficients but also their relative contributions to particulate absorption are significantly different from that in other areas. Note that differences in the bio-optical behaviors of South Pacific and Mediterranean waters were also observed by Morel et al. [2007b] considering the downward irradiance attenuation coefficients $K_{d}$ (which are close to total absorption coefficients).

[33] It is also worth noting that for the BIOSOPE area, the $a_{\text {NAP }}(440) / a_{p}(440)$ ratio shows a significant trend to increase with decreasing Tchl $a$ concentration (see legend of Figure 11), from approximately 0.1 in the upwelling area to $0.2-0.5$ in the SPG, indicating a higher relative concentration of (or more colored?) nonalgal particles when going toward the clearest waters. Such a trend is much less visible when measurements from all geographical regions are pooled together (Figure 11).

\subsubsection{Spatial Variations of the Spectral Slope of Nonalgal Absorption}

[34] For all samples, the spectral dependence of $a_{\text {NAP }}(\lambda)$ was well represented by an exponential function, and the standard error on the $S_{\mathrm{NAP}}$ estimate never exceeded $0.1 \%$. The $S_{\mathrm{NAP}}$ values were found to vary in the range $0.007-$ $0.014 \mathrm{~nm}^{-1}$ (Figure 9c), with an average value of 0.0094 $( \pm 0.0018) \mathrm{nm}^{-1}$. This average value is slightly lower than those found, for example, by Roesler et al. [1989] (0.011 \pm $\left.0.002 \mathrm{~nm}^{-1}\right)$, Bricaud et al. [1998] $\left(0.011 \pm 0.002 \mathrm{~nm}^{-1}\right)$, or Babin et al. [2003] $\left(0.0123 \pm 0.0013 \mathrm{~nm}^{-1}\right)$. This was expected, because our range of values includes the significantly lower slopes measured for waters below the euphotic depth (not included in the previously mentioned studies). Actually, the $S_{\mathrm{NAP}}$ values are spatially well structured (Figure 9c): above the DCM, they remain high $(0.010$ $0.014 \mathrm{~nm}^{-1}$ ) over the whole transect (except around the MAR station), while below the DCM they are mostly in the range $0.007-0.010 \mathrm{~nm}^{-1}$. Maximum values $\left(>0.013 \mathrm{~nm}^{-1}\right)$ appear near the surface between $132^{\circ} \mathrm{W}$ and $125^{\circ} \mathrm{W}$, where the highest abundance of picophytoplankton was observed (see Figure 1b), which suggests that picoplanktonic cells tend to generate (or be associated to) rather "colored" detritus (see next paragraph). 


\section{$a_{\text {nap }}(440)$}
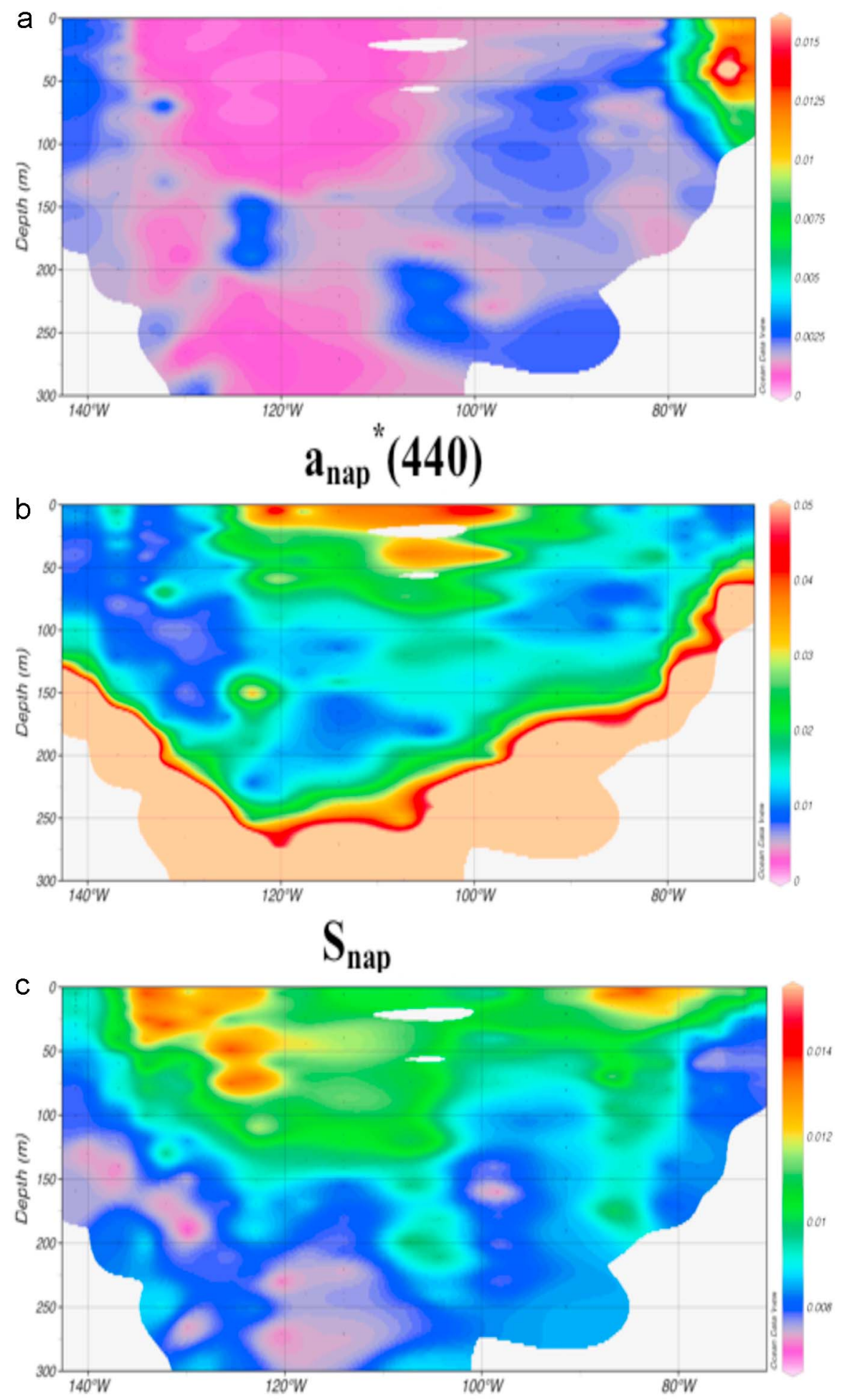

Figure 9. Contour plots of (a) the absorption coefficient of nonalgal particles at $440 \mathrm{~nm}, a_{\mathrm{NAP}}(440)\left(\mathrm{in} \mathrm{m}^{-1}\right)$, (b) the chl-specific absorption coefficient of nonalgal particles at $440 \mathrm{~nm}, a_{\mathrm{NAP}} *(440)$ (in $\mathrm{m}^{2} \mathrm{mg}^{-1}$ ), and (c) the slope of the absorption spectrum of nonalgal particles, $S_{\mathrm{NAP}}\left(\right.$ in $\left.\mathrm{nm}^{-1}\right)$, for the cruise transect. 

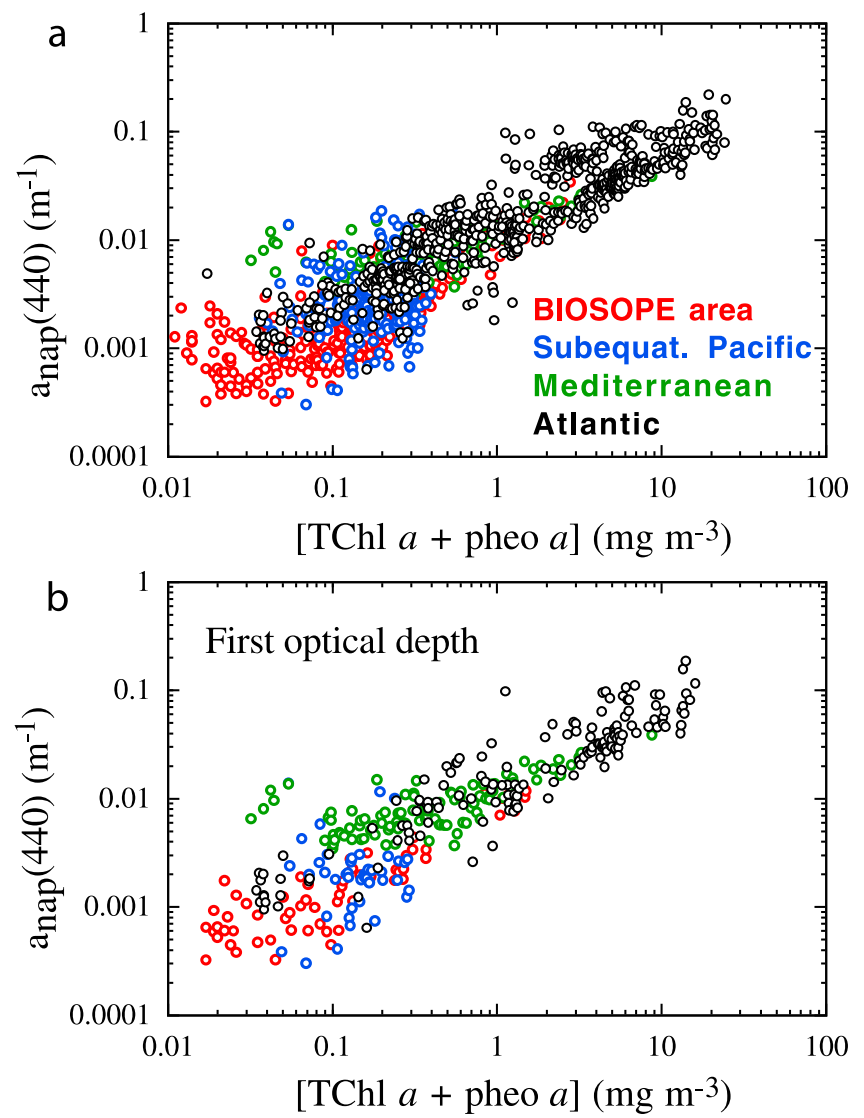

Figure 10. Variations of the absorption coefficient of nonalgal particles at $440 \mathrm{~nm}, a_{\mathrm{NAP}}(440)$, as a function of the [Tchl $a+$ pheo $a$ ] concentration (a) for all depths and (b) for the first optical depth, for various areas.

[35] In their study of the optical properties of surface coastal waters around Europe, Babin et al. [2003] suggested that the observed variations in $S_{\mathrm{NAP}}$ were mostly related to the proportion of mineral and organic matter, as $S_{\mathrm{NAP}}$ values were spanning a relatively narrow range $\left(0.0109-0.0137 \mathrm{~nm}^{-1}\right)$ for the various sites with predominantly organic particles (Mediterranean, Adriatic, Atlantic, and Baltic seas). In contrast, over the BIOSOPE area, where mineral matter inputs are negligible, the $S_{\mathrm{NAP}}$ values cover a large range, from approximately 0.008 to $0.016 \mathrm{~nm}^{-1}$ in the surface layer. This suggests that the presence of organic particles of different nature (biogenous detritus, heterotrophs, etc.), coexisting in variable proportions within the nonalgal pool, may lead to significant variations in $S_{\mathrm{NAP}}$ values. Although poorly correlated to algal biomass (Figure 12a) and $a_{\mathrm{NAP}}(440)$ (Figure $12 \mathrm{~b}$ ), the $S_{\mathrm{NAP}}$ values show a significant decreasing trend (see legend of Figure 12b) with increasing $a_{\mathrm{NAP}}(440)$ values (both within the first optical depth and in deeper waters). In the upwelling area, however, high $S_{\mathrm{NAP}}$ values $\left(>0.01 \mathrm{~nm}^{-1}\right)$ are associated with high $a_{\mathrm{NAP}}(440)$ values (around $0.01 \mathrm{~m}^{-1}$ ). This indicates that there occurs a continuous variation in the composition of the nonalgal pool from the clearest waters of the SPG (colored particles in low concentrations) to mesotrophic waters around the Marquesas Islands (weakly colored particles in higher concentrations); in the upwelling area, conversely, nonalgal particles are both abundant and colored.

\subsection{Light Absorption by CDOM}

\subsubsection{Spatial Variations of CDOM Absorption}

[36] In the surface layer, the $a_{\mathrm{CDOM}}(440)$ values are the lowest $\left(<0.01 \mathrm{~m}^{-1}\right)$ in the center of the SPG and increase progressively toward mesotrophic and eutrophic waters, reaching more than $0.04 \mathrm{~m}^{-1}$ in the upwelling area (Figure 13a). Except in this area (where values are relatively stable within the $0-50 \mathrm{~m}$ layer and decrease below), $a_{\mathrm{CDOM}}(440)$ values tend to increase within the DCM, by approximately a factor of 2, compared to the surface layer (Figure 13a). Such an increase with depth has already been observed in the equatorial Pacific [Pegau, 1996]. The low values of CDOM absorption in the surface layer, compared to that in deeper waters, suggest that photobleaching has a major, if not dominant, role in controlling the CDOM concentration near the surface [e.g., Chen and Bada, 1992].
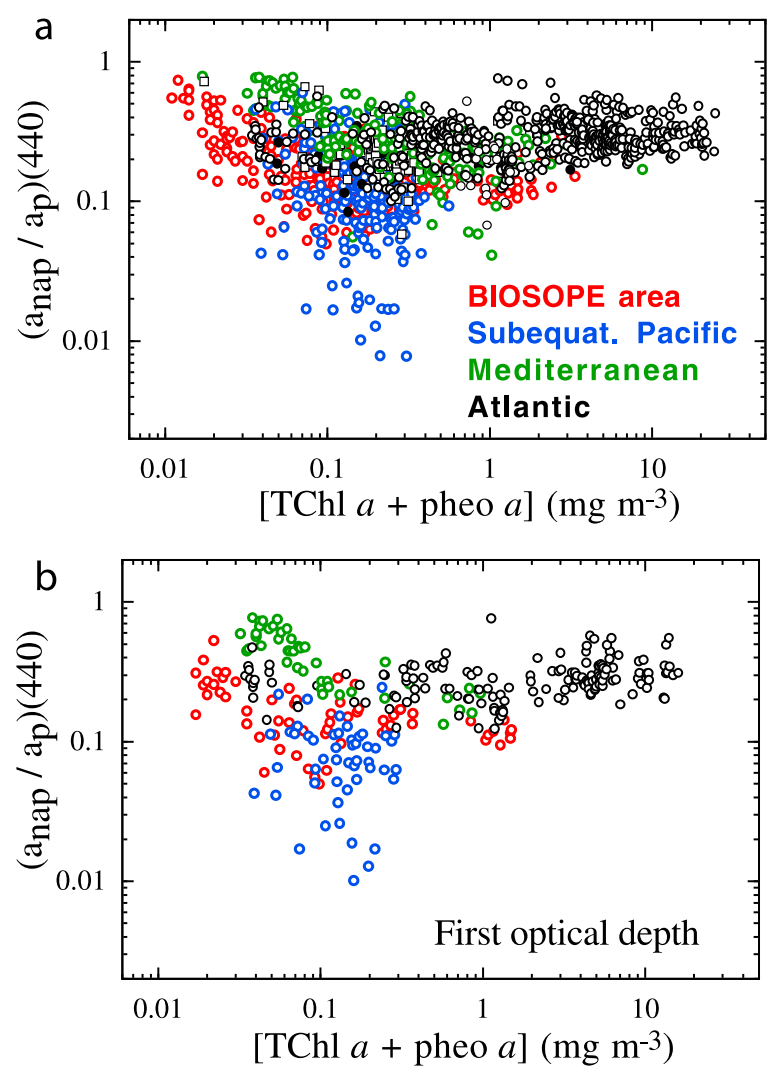

Figure 11. Variations of the nonalgal-to-total-particulateabsorption ratio $a_{\mathrm{NAP}} / a_{p}$ at $440 \mathrm{~nm}$ as a function of the [Tchl $a+$ pheo $a$ ] concentration (a) for all depths and (b) for the first optical depth, for various areas. Average values (log-transformed data) for each area were compared using a Fisher protected least significant difference (PLSD) test. All of them were found to be significantly different $(p<0.0001)$, except the Mediterranean and Atlantic values. For BIOSOPE measurements, the average values for the two groups corresponding to chlorophyll concentrations less than or greater than $0.01 \mathrm{mg} \mathrm{m}^{-3}$, respectively, were also found to be significantly different (Fisher PLSD test, $p<0.0001$ ). 

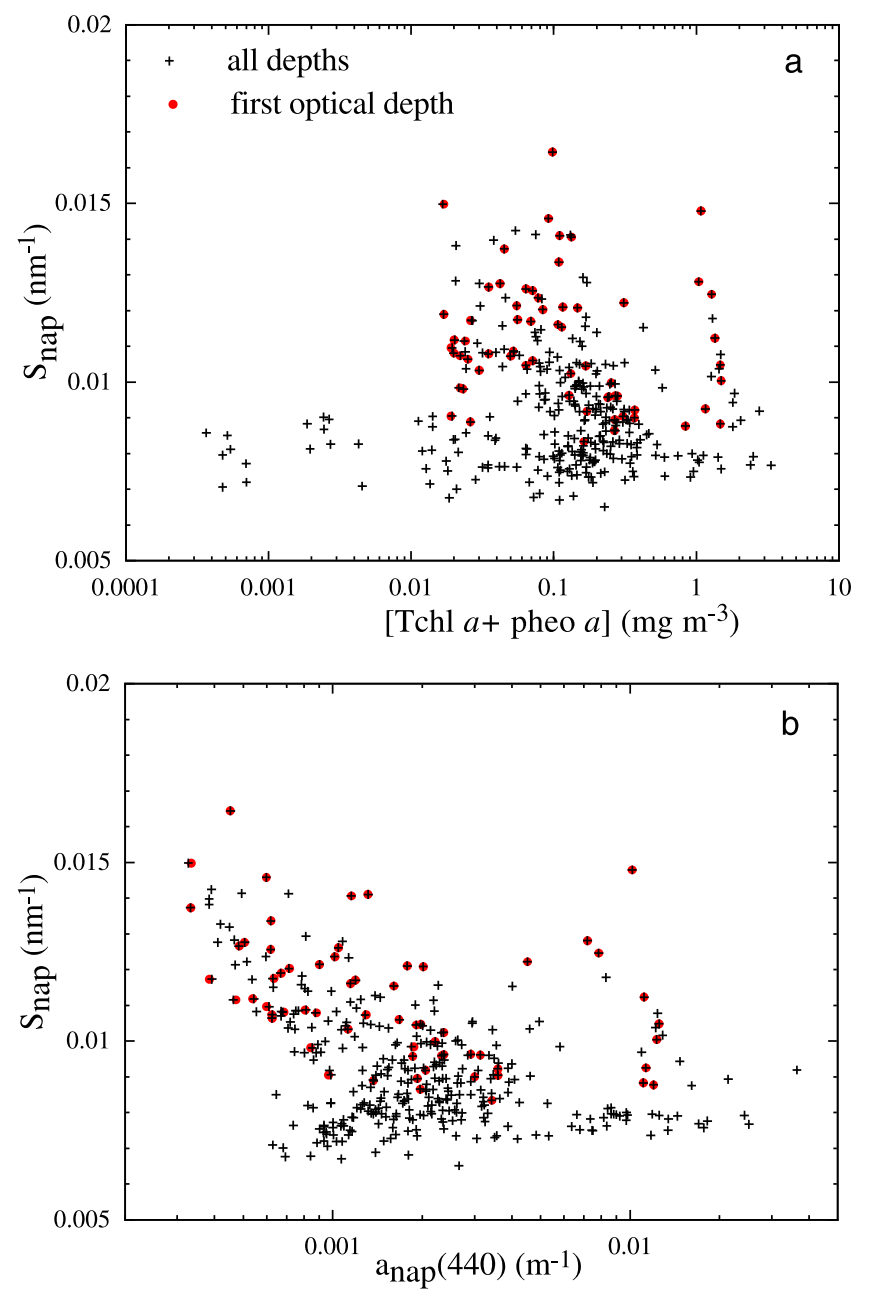

Figure 12. Variations of the slope of the absorption spectrum of nonalgal particles, $S_{\mathrm{NAP}}$, (a) as a function of the [Tchl $a+$ pheo $a$ ] concentration and (b) as a function of the absorption coefficient $a_{\mathrm{NAP}}(440)$, for the BIOSOPE area. Average $S_{\mathrm{NAP}}$ values corresponding to $a_{\mathrm{NAP}}(440)<$ $0.002 \mathrm{~m}^{-1}$ and $a_{\mathrm{NAP}}(440)>0.002 \mathrm{~m}^{-1}$ were compared using a Fisher PLSD test and were found to be significantly different $(p<0.0001)$.

[37] The overall range of variation of $a_{\mathrm{CDOM}}(440)$ is slightly narrower than those of $a_{\phi}$ (440) and $a_{\mathrm{NAP}}(440)$ : approximately 1.5 orders of magnitude (from 0.001 to $\left.0.06 \mathrm{~m}^{-1}\right)$ instead of two orders of magnitude for $a_{\phi}(440)$ and $a_{\mathrm{NAP}}(440)$. (note that values around $0.001 \mathrm{~m}^{-1}$ correspond to optical densities around $8.6 \times 10^{-4}$, which are only slightly above the detection limit of the instrument.) The $a_{\mathrm{CDOM}}(440)$ values covary with the Tchl $a$ concentration, but with a very high scatter (Figure 14a). Such variability in the relationship was expected, because the vertical variations of Tchl $a$ concentration and CDOM absorption do not show any similarity (see Figures 3a and 13a). When the data set is restricted to the first optical depth, the scatter is strongly reduced, with $72 \%$ of the variability in $a_{\mathrm{CDOM}}(440)$ accounted for by the Tchl $a$ concentration:

$$
a_{\mathrm{CDOM}}(440)=0.034 \mathrm{Tchl} a^{0.619}\left(r^{2}=0.72, N=45\right) .
$$

A similar relationship can be established for the wavelength $370 \mathrm{~nm}$ :

$$
a_{\mathrm{CDOM}}(370)=0.089 \operatorname{Tchl} a^{0.650}\left(r^{2}=0.79, N=45\right),
$$

with the aim to compare it with that derived by Morel et al. [2007a] over the same area, by inverting total absorption coefficients from measured apparent optical properties (diffuse attenuation coefficients and diffuse reflectances) and then subtracting the absorption coefficient of pure water and the measured particulate absorption coefficients,

$$
a_{\mathrm{CDOM}}(370)=0.100 \mathrm{Tchl} a^{0.80}\left(r^{2}=0.94, N=27\right)
$$

The agreement between both relationships is quite good (Figure 14b), which suggests that the closure between inherent (absorption coefficients) and apparent optical properties over the transect is rather well achieved. Part of the scatter around equation (5b) might be artifactual (due to measurement errors, especially for low CDOM contents). Several studies, however, have shown that, even in the open ocean, the part of the variance in $a_{\mathrm{CDOM}}$ explained by algal biomass is generally rather low [e.g., Bricaud et al., 1981; Reynolds et al., 2001]. Both the general trend (progressive increase in $a_{\text {CDOM }}$ from the SPG to the upwelling area) and the scatter observed in Figure 14 are consistent with the assumption made several decades ago [Kopelevich and Burenkov, 1977] that CDOM is a long-lived product of phytoplankton degradation and reflects the average biological activity in the considered area, whereas small-scale changes in biomass do not necessarily induce changes in the CDOM content.

\subsubsection{Spatial Variations of the Spectral Slope of CDOM Absorption}

[38] Over the transect, the spectral slope values, $S_{\mathrm{CDOM}}$, span the range $0.007-0.032 \mathrm{~nm}^{-1}$ (Figure 13b) with an average value of $0.0145( \pm 0.0034) \mathrm{nm}^{-1}$. Standard errors on the $S_{\mathrm{CDOM}}$ estimates vary between $0.4 \%$ and $4.6 \%$, with an average value of $1.6 \%$ for the whole data set. While the average value of $S_{\mathrm{CDOM}}$ is similar to many previous observations [e.g., Bricaud et al., 1981; Blough et al., 1993; Barnard et al., 1998], the variation range over the transect is surprisingly large. Even if it has been acknowledged that a large part of the variability in the published $S_{\mathrm{CDOM}}$ values results from the use of different spectral ranges [Twardowski et al., 2004], the present results confirm that $S_{\mathrm{CDOM}}$ is also subject to a large actual variability. Several authors have suggested that these variations provide information on the history of the CDOM pool; for example, they may reflect the relative proportions of humic and fulvic acids in the CDOM pool [Carder et al., 1989], the relative contributions of biologically semilabile and more refractory fractions [Nelson and Siegel, 2002], or the selective bleaching of some CDOM components by sunlight, which induces a shift from complexes of high molecular weight to smaller complexes absorbing at shorter wavelengths [Whitehead et al., 2000; Twardowski and Donaghay, 2002]. These various phenomena are expected to vary both horizontally and vertically. 

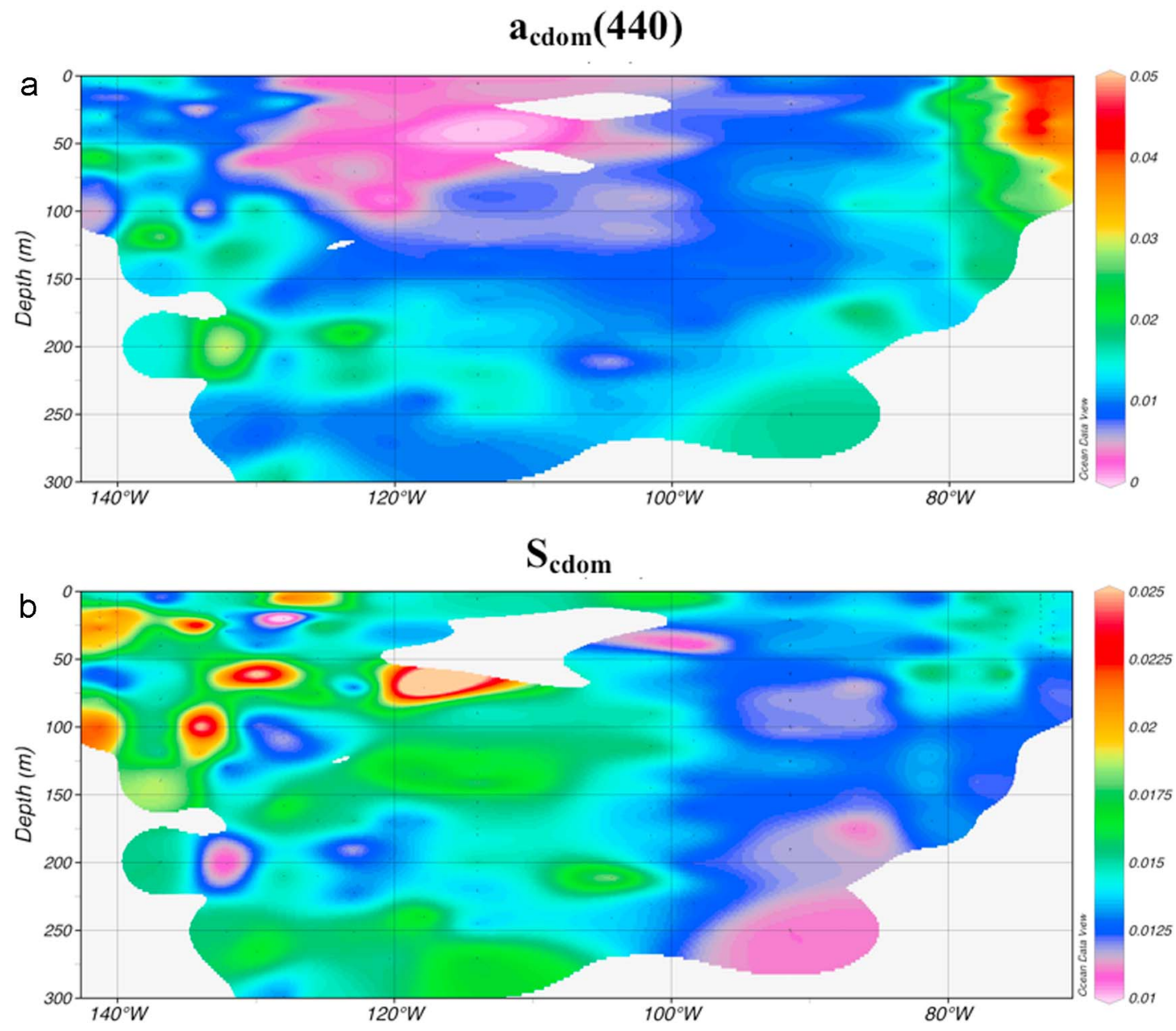

Figure 13. Contour plots of (a) the absorption coefficient of CDOM at $440 \mathrm{~nm}, a_{\mathrm{CDOM}}(440)$ (in $\mathrm{m}^{-1}$ ), and (b) the slope of the absorption spectrum of CDOM, $S_{\mathrm{CDOM}}\left(\right.$ in $\left.\mathrm{nm}^{-1}\right)$, for the cruise transect.

[39] Although not strongly spatially structured, the $S_{\mathrm{CDOM}}$ values show a clear tendency to decrease when going from the SPG toward the upwelling area (Figure 13b). The decrease around $100^{\circ} \mathrm{W}$ corresponds to the transition between ESPCW and the SASW and is associated with a strong decrease in salinity (Figure $2 \mathrm{~b}$ ). The $S_{\mathrm{CDOM}}$ values show no relationship with the Tchl $a$ concentration (Figure 15a), but covary inversely with CDOM absorption (Figure 15b), which is consistent with numerous previous observations [e.g., Carder et al., 1989; Nelson and Siegel, 2002]. The large variability in $S_{\mathrm{CDOM}}$ for low $a_{\mathrm{CDOM}}(440)$ values has been pointed out by several authors [e.g., Vodacek et al., 1997]. It is likely partly artifactual (i.e., due to increasing experimental errors for waters with low CDOM contents) but might also result from various actual phenomena (photobleaching, variable nature of CDOM, etc.), as mentioned in the previous paragraph.

[40] Examples of $a_{\mathrm{CDOM}}$ spectra, for three stations (MAR, GYR, and UPW) representing the typical trophic regimes encountered during the transect, are shown in Figure 16. Besides the general exponential dependence of $a_{\text {CDOM }}$ over the whole UV-visible domain, one noticeable feature is the "bump" of absorption around 410-420 nm on some spectra, especially those measured in the upwelling area from the surface down to $100 \mathrm{~m}$. It is virtually absent in the surface layer of oligotrophic and mesotrophic areas and appears with increasing depth in these areas. This is the case also for pheopigments (pheophytin $a$ and pheophorbide $a$, which present an absorption maximum around $410 \mathrm{~nm}$ ), which suggests that this bump could be produced by pheopigments, either naturally present in the dissolved phase in seawater or released from cells during the filtration process.

\subsection{Relative Contributions of the Three Components to Total Nonwater Absorption}

[41] The relative contributions of phytoplankton, nonalgal particles, and CDOM to total nonwater absorption can be derived at any wavelength from the optical measurements performed in the BIOSOPE area. Note that, while the uncertainty of individual absorption coefficients is about $15 \%$, the uncertainty of absorption ratios is expected to be lower, because some sources of error (e.g., the $\beta$ factor) simultaneously affect the $a_{p}, a_{\phi}$, and $a_{\mathrm{NAP}}$ coefficients. The absorption budgets are presented here at two wavelengths, 440 and $380 \mathrm{~nm}$ (Figure 17). Similar to $440 \mathrm{~nm}$, the wavelength $380 \mathrm{~nm}$ is relevant to remote sensing applications, because it corresponds (or is close) to the UV channel of some historical (e.g., GLI), current (HICO) and future (e.g., S-GLI) ocean color sensors. 

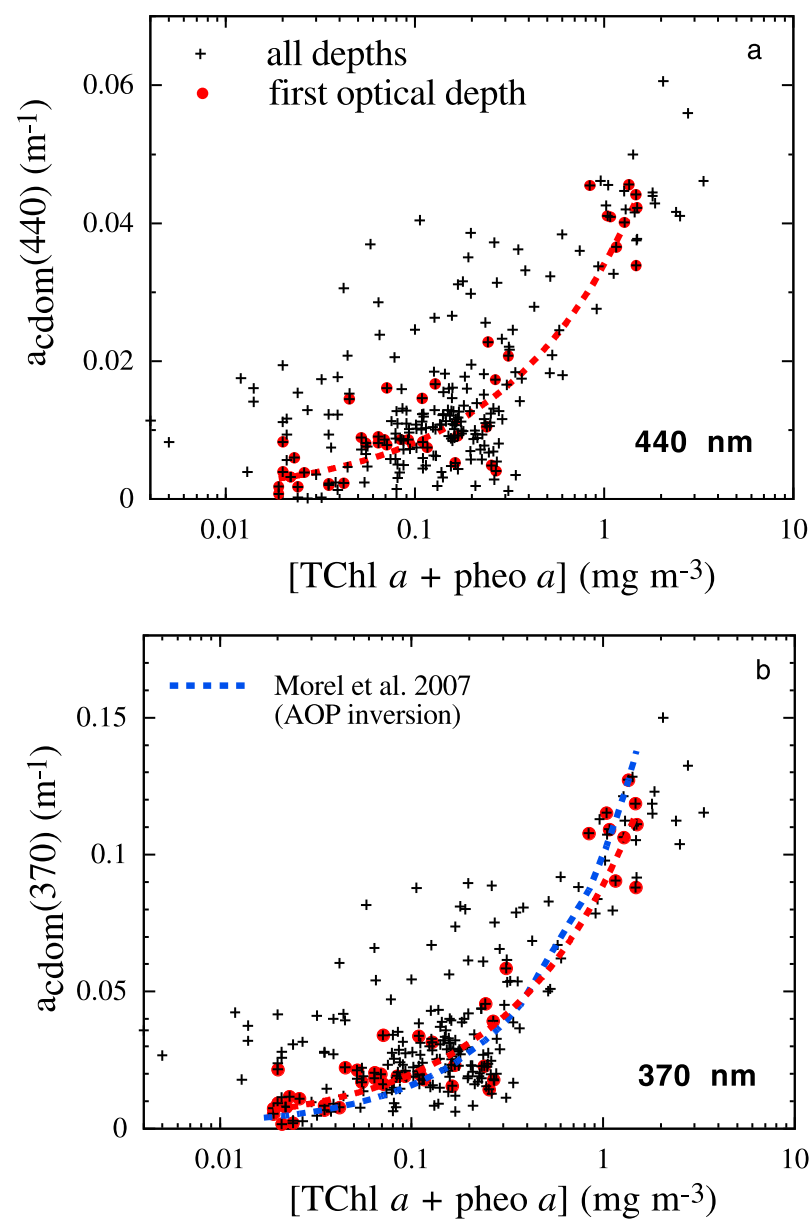

Figure 14. (a) Variations of the CDOM absorption coefficient at $440 \mathrm{~nm}$ as a function of the [Tchl $a+$ pheo $a]$ concentration for the BIOSOPE area. The regression line obtained when the data set is restricted to the first optical depth [equation (5a)] is shown as a dashed line. (b) Same as Figure $14 \mathrm{a}$, for the wavelength $370 \mathrm{~nm}$. The regression line obtained when the data set is restricted to the first optical depth [equation $(5 b)]$ is shown as a dashed line. The regression line obtained by Morel et al. [2007a] for the same area is shown for comparison.

[42] One striking, and rather unexpected, feature is that, whatever the considered wavelength, the relative contributions of each component within the euphotic layer are only weakly variable with the trophic state of the waters. At $440 \mathrm{~nm}$, and over the whole area, phytoplankton contribute to $30-60 \%$ of total nonwater absorption from the surface to the DCM. This contribution decreases to $<30 \%$ below the DCM. Nonalgal particles contribute to $10-20 \%$ in the surface layer of the SPG and to $10 \%$ or less elsewhere. Over the whole area, CDOM contributes to $40-50 \%$ of total nonwater absorption from the surface to the DCM, while its contribution increases toward $90-100 \%$ below the DCM. Therefore, from the surface to the DCM, the relative contributions of phytoplankton and CDOM to total nonwater absorption are rather similar at $440 \mathrm{~nm}$, whereas nonalgal particles appear to be a minor component. These figures lead to a relative contribution of CDM (at $440 \mathrm{~nm}$ ) of around 50-60\% near the surface, which is quite in the range of satellite estimates (using the Garver-
Siegel-Maritorena (GSM) model) provided by Siegel et al. [2002, Figure 2] for the same area.

[43] At $380 \mathrm{~nm}$, the relative contributions are completely modified, as expected, and the major contribution (60-80\% of total nonwater absorption) becomes that of CDOM, whatever the area and depth. The dominant influence of CDOM on light absorption in this wavelength domain has long been recognized [e.g., Nelson et al., 1998, and references therein]. At this wavelength, phytoplankton and nonalgal particles contribute much more weakly, and for similar parts (10-20\%), to total nonwater absorption.

[44] It is also interesting to consider the contribution of pure seawater to total absorption coefficients, and its spatial variations over the transect (Figure 18). While this contribution is less than $15 \%$ in the upwelling area, it exceeds $40 \%$ in the whole SPG (at both 440 and $380 \mathrm{~nm}$ ) and can be locally as high as $70 \%$ at $440 \mathrm{~nm}$. Therefore, while in most oceanic systems light availability at blue wavelengths is essentially
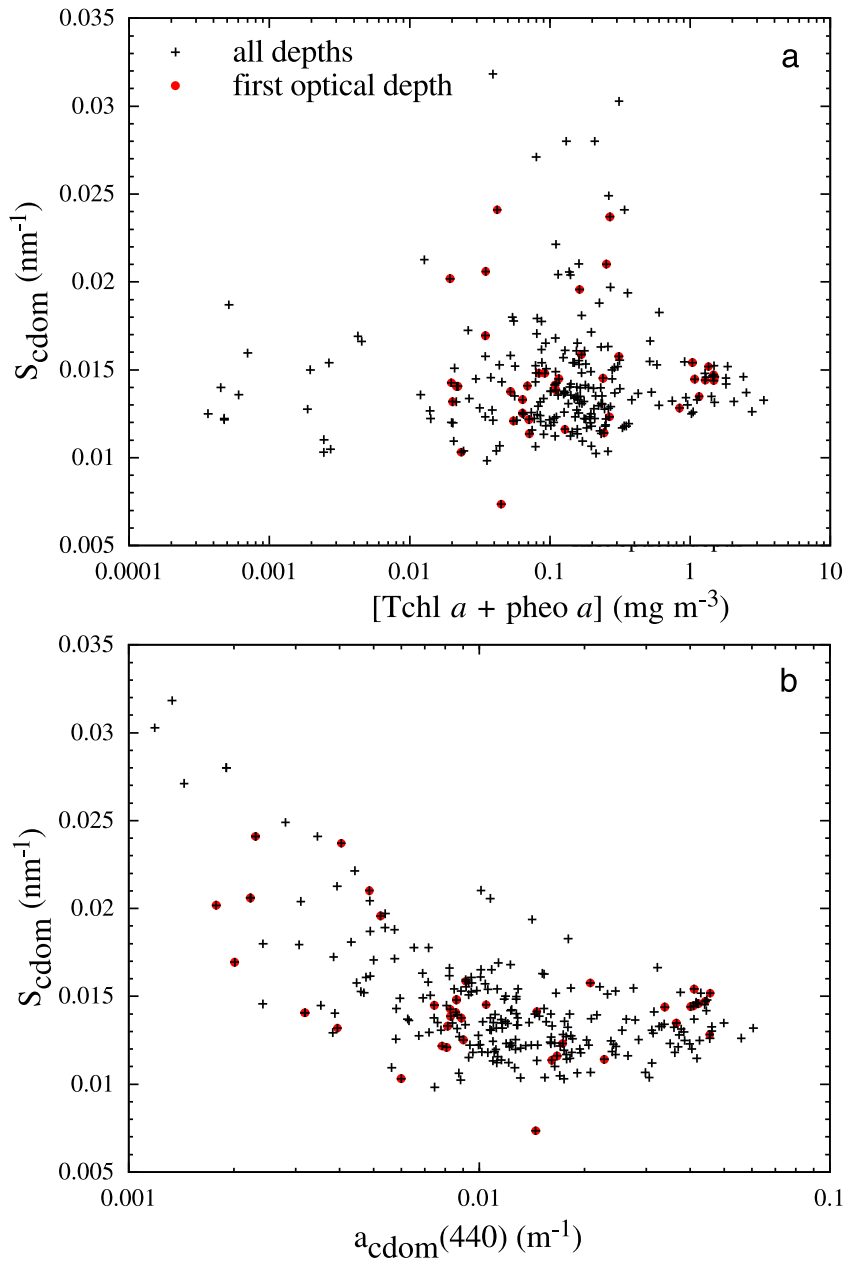

Figure 15. Variations of the slope of the CDOM absorption spectrum $S_{\mathrm{CDOM}}$ (a) as a function of the [Tchl $a+$ pheo $\left.a\right]$ concentration and (b) as a function of the CDOM absorption coefficient at $440 \mathrm{~nm}, a_{\mathrm{CDOM}}(440)$, for the BIOSOPE area. Average $S_{\mathrm{CDOM}}$ values corresponding to $a_{\mathrm{CDOM}}(440)<$ $0.008 \mathrm{~m}^{-1}$ and $a_{\mathrm{CDOM}}(440)>0.008 \mathrm{~m}^{-1}$ were compared using a Fisher PLSD test and were found to be significantly different $(p<0.0001)$. 


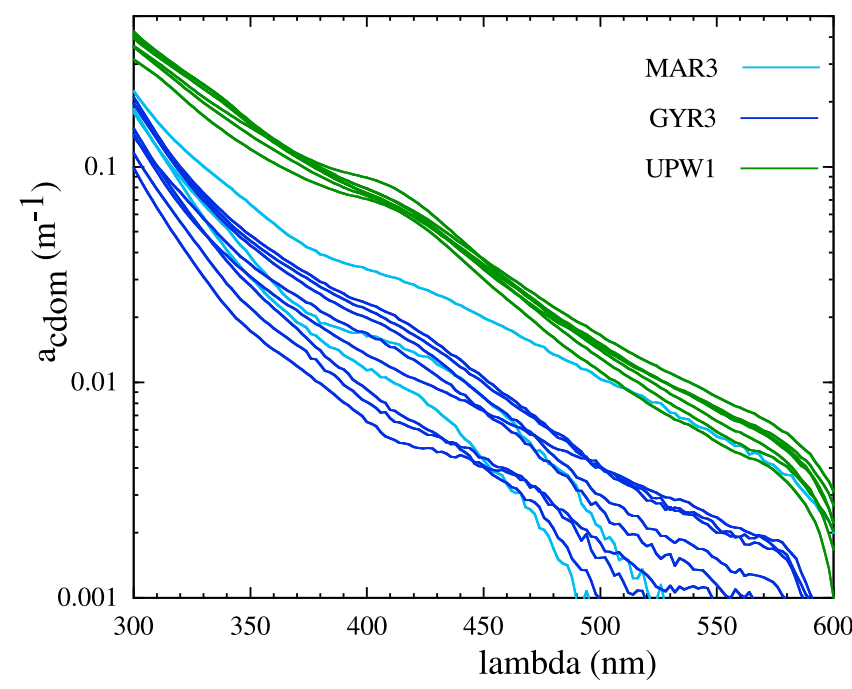

Figure 16. Examples of CDOM absorption spectra measured at three stations: the mesotrophic station MAR (day 3), the hyperoligotrophic station GYR (day 3), and the upwelling station UPW (day 1) (see Figure 1 for the locations of the stations).
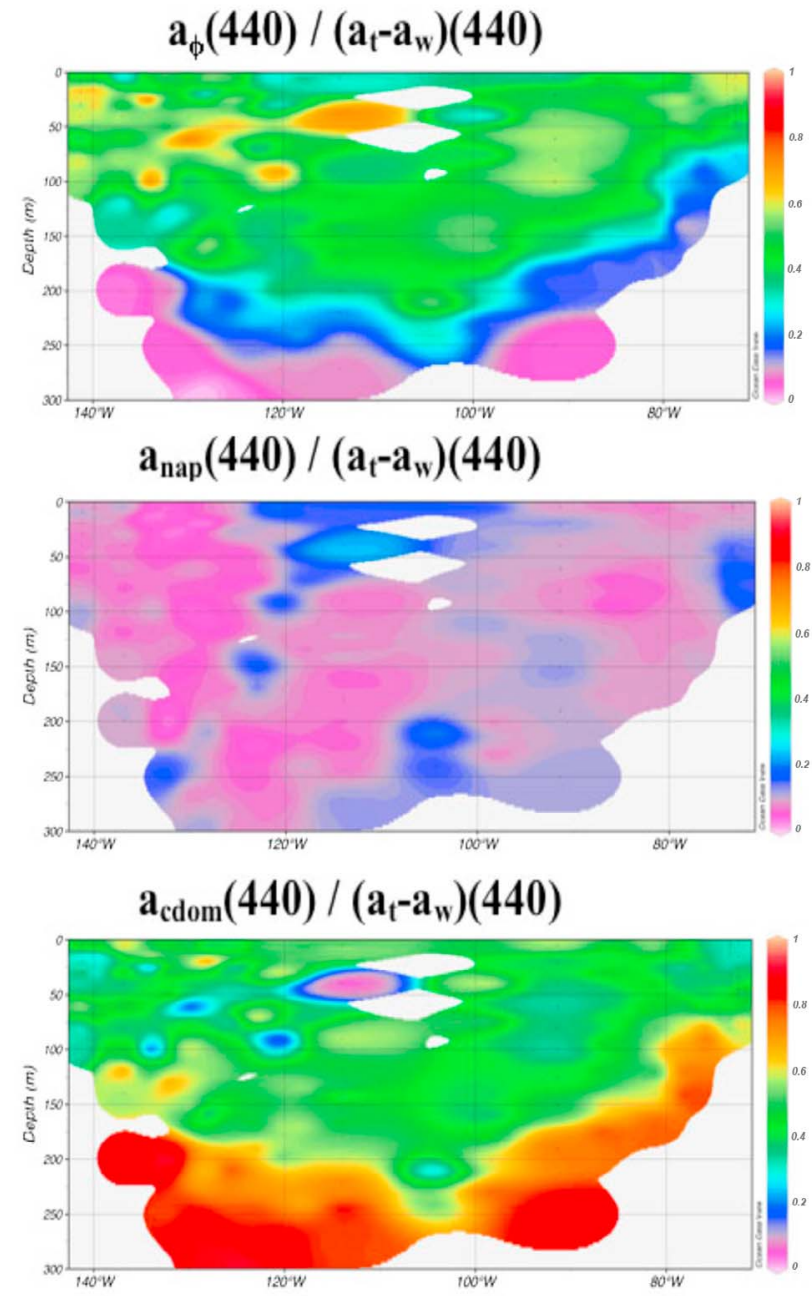

ruled by phytoplankton and associated biogenous matter, in the particular system of the SPG, pure water becomes the dominant factor ruling this light availability, at least above the DCM.

\section{Summary and Conclusions}

[45] The absorption coefficients of phytoplankton, nonalgal particles, and CDOM measured along the BIOSOPE transect showed a large variability in accordance with the variety of trophic states encountered. In the South Pacific Gyre, they were among the lowest ever reported for open ocean waters.

[46] Although the absorption coefficients of phytoplankton, $a_{\phi}(\lambda)$, measured in the Chile upwelling area were in good agreement with previously published parameterizations for the $440 \mathrm{~nm}$ wavelength [Bricaud et al., 1998, 2004], in the oligotrophic and mesotrophic waters of the sampled area, they were lower than expected from the average relationships. These lower coefficients (compared to waters with a similar Tchl $a$ content) were found to originate from a lower (relative to Tchl $a$ ) nonphotosynthetic carotenoïd content combined with a larger average cell size.
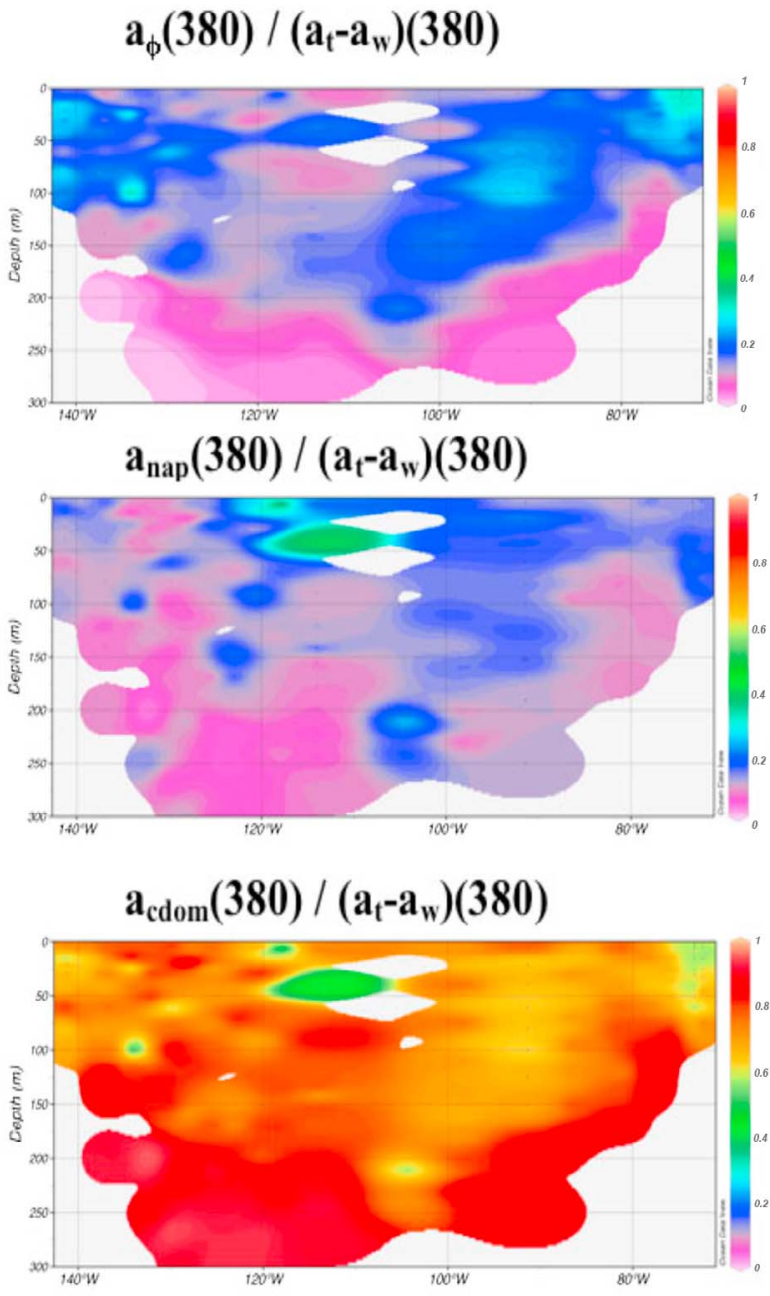

Figure 17. Contour plots of the relative contributions of phytoplankton, nonalgal particles, and CDOM to total nonwater absorption, for two different wavelengths: (left) $440 \mathrm{~nm}$ and (right) $380 \mathrm{~nm}$. 


\section{$a_{w}(440) / a_{t}(440)$}
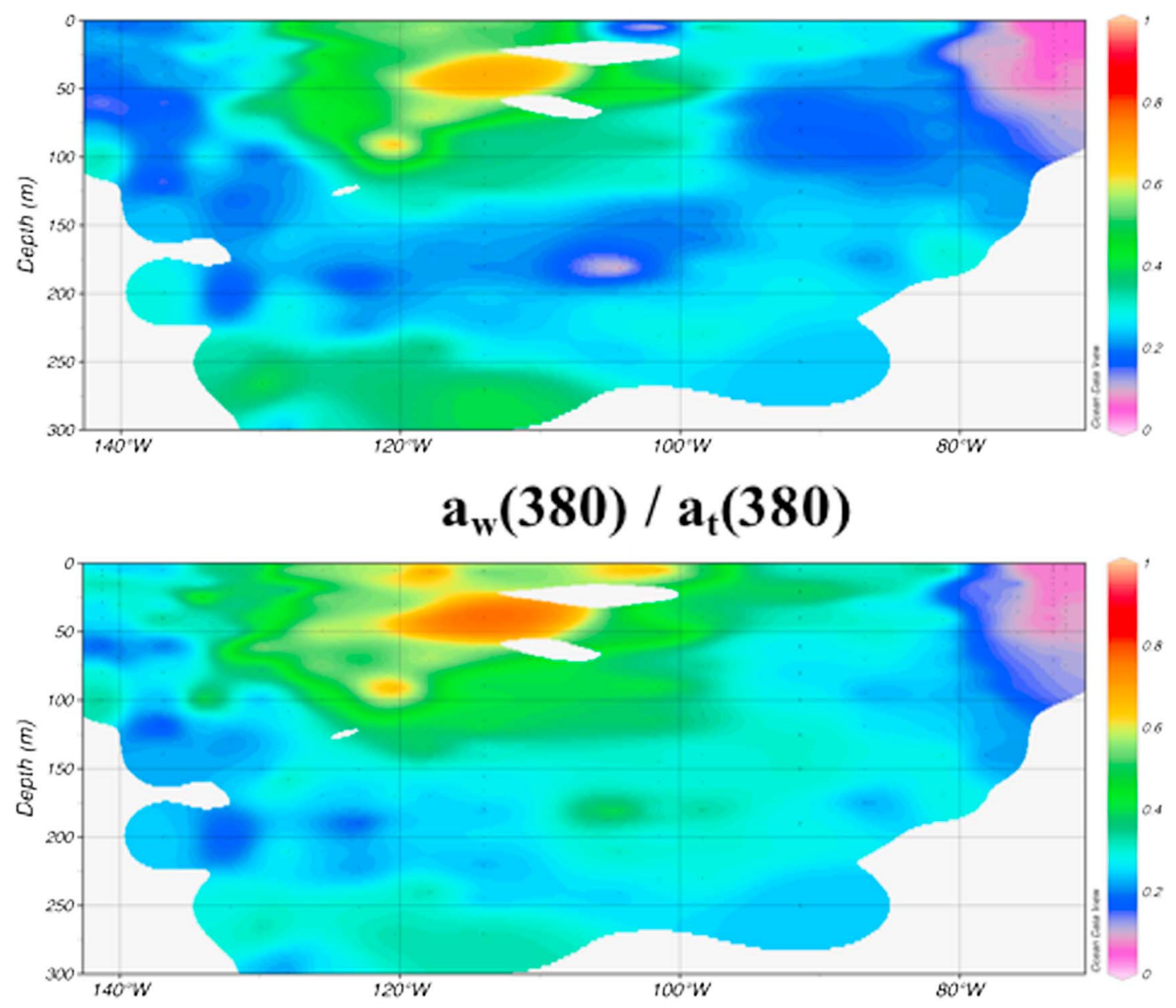

Figure 18. Contour plots of the relative contribution of pure seawater to the total absorption coefficient, at (top) $440 \mathrm{~nm}$ and (bottom) $380 \mathrm{~nm}$. Absorption coefficients of pure water used for computations are those published by Pope and Fry [1997].

[47] The absorption coefficients of nonalgal particles, $a_{\mathrm{NAP}}(\lambda)$, were also lower (at $440 \mathrm{~nm}$ ) than those previously observed in most other areas, with the exception of the subequatorial Pacific. Over the BIOSOPE transect, the contribution of nonalgal particles to total particulate absorption $\left(a_{\mathrm{NAP}} / a_{p}\right.$ at $\left.440 \mathrm{~nm}\right)$ was found to decrease with increasing Tchl $a$ concentration, indicating the presence of proportionally more numerous, or more colored, nonalgal particles in the SPG compared to the upwelling area. Note, however, that for a given Tchl $a$ content, this contribution was on average lower in South Pacific waters than in other (Atlantic or Mediterranean) sites. The spectral slope of absorption by nonalgal particles $\left(S_{\mathrm{NAP}}\right)$ showed large $\left(0.007-0.014 \mathrm{~nm}^{-1}\right)$, and spatially structured, variations over the whole area, indicating large variations in the composition of the nonalgal pool. Such variations have generally been related to variable proportions in mineral and organic matters and have been very seldom evidenced in oceanic areas with negligible mineral inputs.

[48] The absorption coefficients of CDOM could be measured in the clearest waters of the world ocean thanks to an instrument equipped with a $2 \mathrm{~m}$ capillary cell. These coefficients varied over a large range across the sampled area, although this range was narrower than those observed for phytoplankton and nonalgal particles ( 1.5 instead of 2 orders of magnitude at $440 \mathrm{~nm}$ ). They were also found to covary with algal biomass in the surface layer, and the observed relationship was in good agreement with that derived from inversion of apparent optical properties. More systematic measurements of CDOM absorption will be needed in various environments to confirm the existence, and the spatial and temporal variability, of such relationships which could be directly usable in bio-optical models. It must be kept in mind, however, that a large scatter affects these relationships, which is consistent with the fact that the CDOM concentration reflects an average of the biological activity rather than short-term changes in algal biomass.

[49] The slope values for CDOM absorption $\left(S_{\mathrm{CDOM}}\right)$ varied over a surprisingly large range for the open ocean $\left(0.0145 \pm 0.0034 \mathrm{~nm}^{-1}\right)$. Although not strongly spatially structured, and not related to the Tchl $a$ content of waters, the $S_{\mathrm{CDOM}}$ values were observed to vary inversely to $a_{\mathrm{CDOM}}(440)$. 
Previously published studies have already emphasized such inverse relationships, but they dealt mostly with coastal environments. The present study suggests that such relationships could be applicable to the open ocean. This could be exploited for an improved representation of the CDOM contribution to total absorption in bio-optical models, to the extent that more is known on the spatial and temporal variability of such relationships.

[50] The present study has also demonstrated, somewhat surprisingly, that the relative contributions of phytoplankton, nonalgal particles, and CDOM to nonwater absorption are rather weakly variable with the trophic state of waters, at least within the euphotic layer. As expected, these contributions are, in contrast, highly dependent on the considered wavelength: at $440 \mathrm{~nm}$, the major contributors were observed to be phytoplankton and CDOM, with similar contributions (around 40-50\%), whereas at $380 \mathrm{~nm}$, the main contributor was CDOM $(>60 \%)$. Such absorption budgets can be derived for each relevant wavelength and could contribute both to the improvement of bio-optical models and to the validation of current approaches that provide satellite estimates of CDM and phytoplankton absorption for the considered area.

[51] Acknowledgments. This is a contribution to the BIOSOPE project of the LEFE-CYBER program. The BIOSOPE project was funded by the Centre National de la Recherche Scientifique (CNRS), the Institut des Sciences de l'Univers (INSU), the Centre National d'Etudes Spatiales (CNES), the European Space Agency (ESA), NASA, and the Natura Sciences and Engineering Research Council of Canada (NSERC). The BIOSOPE cruise program was managed by H. Claustre and A. Sciandra. We express our gratitude to the captain and crew of the R/V Atalante for their help in shipboard operations, to D. Tailliez and C. Bournot for their competent CTD rosette management and data processing, and to B. Gentili for help in programming.

\section{References}

Allali, K., A. Bricaud, and H. Claustre (1997), Spatial variations in the chlorophyll-specific absorption coefficients of phytoplankton and photosynthetically active pigments in the equatorial Pacific, J. Geophys. Res., 102(C6), 12,413-12,423, doi:10.1029/97JC00380.

Babin, M., D. Stramski, G. M. Ferrari, H. Claustre, A. Bricaud, G. Obolensky, and N. Hoepffner (2003), Variations in the light absorption coefficients of phytoplankton, nonalgal particles, and dissolved organic matter in coastal waters around Europe, J. Geophys. Res., 108(C7), 3211, doi:10.1029/2001JC000882.

Barnard, A. H., W. S. Pegau, and J. R. V. Zaneveld (1998), Global relationships of the inherent optical properties of the oceans, J. Geophys. Res., 103(C11), 24,955-24,968, doi:10.1029/98JC01851.

Blough, N. V., O. C. Zafiriou, and J. Bonilla (1993), Optical absorption spectra of waters from the Orinoco River outflow: Terrestrial input of colored organic matter to the Caribbean, J. Geophys. Res., 98(C2), 2271-2278, doi:10.1029/92JC02763.

Bricaud, A. (2002), Inherent optical properties of particles in case 1 waters: The various parameterizations and their consistency, paper presented at Ocean Optics XVI, Sponsors were Office of Naval Research, NASA and The Oceanography Society, Santa Fe, N. M.

Bricaud, A., and D. Stramski (1990), Spectral absorption coefficients of living phytoplankton and nonalgal biogenous matter: A comparison between the Peru upwelling area and the Sargasso Sea, Limnol. Oceanogr., 35, 562-582.

Bricaud, A., A. Morel, and L. Prieur (1981), Absorption by dissolved organic matter of the sea (yellow substance) in the UV and visible domains, Limnol. Oceanogr., 26, 43-53, doi:10.4319/1o.1981.26.1.0043.

Bricaud, A., M. Babin, A. Morel, and H. Claustre (1995), Variability in the chlorophyll-specific absorption coefficient of natural phytoplankton: Analysis and parameterization, J. Geophys. Res., 100(C7), 13,32113,332, doi:10.1029/95JC00463.

Bricaud, A., A. Morel, M. Babin, K. Allali, and H. Claustre (1998), Variations of light absorption by suspended particles with the chlorophyll $a$ concentration in oceanic (case 1) waters: Analysis and implications for bio-optical models, J. Geophys. Res., 103(C13), 31,033-31,044, doi:10.1029/98JC02712.

Bricaud, A., H. Claustre, J. Ras, and K. Oubelkheir (2004), Natural variability of phytoplankton absorption in oceanic waters: Influence of the size structure of algal populations, J. Geophys. Res., 109, C11010, doi:10.1029/2004JC002419.

Brown, C. A., Y. Huot, P. J. Werdell, B. Gentili, and H. Claustre (2008), The origin and global distribution of second order variability in satellite ocean color and its potential applications to algorithm development, Remote Sens. Environ., 112, 4186-4203, doi:10.1016/j.rse.2008.06.008

Carder, K. L., R. G. Steward, G. R. Harvey, and P. B. Ortner (1989), Marine humic and fulvic acids: Their effects on remote sensing of ocean chlorophyll, Limnol. Oceanogr., 34, 68-81.

Chen, R. F., and J. L. Bada (1992), The fluorescence of dissolved organic matter in seawater, Mar. Chem., 37, 191-221, doi:10.1016/0304-4203 (92)90078-O.

Ciotti, A. M., and A. Bricaud (2006), Retrievals of a size parameter for phytoplankton and spectral light absorption by colored detrital matter from water-leaving radiances at SeaWiFS channels in a continental shelf region off Brazil, Limnol. Oceanogr. Methods, 4, 237-253.

Claustre, H., and S. Maritorena (2003), The many shades of ocean blue, Science, 302, 1514-1515, doi:10.1126/science.1092704

Claustre, H., et al. (2004), An intercomparison of HPLC phytoplankton methods using in situ samples: Application to remote sensing and database activities, Mar. Chem., 85, 41-61, doi:10.1016/j.marchem. 2003.09.002.

Claustre, H., A. Sciandra, and D. Vaulot (2008), Introduction to the special section bio-optical and biogeochemical conditions in the South East Pacific in late 2004: The BIOSOPE program, Biogeosciences, 5, 679-691.

Cleveland, J. S. (1995), Regional models for phytoplankton absorption as a function of chlorophyll $a$ concentration, J. Geophys. Res., 100, 13,33313,344, doi:10.1029/95JC00532.

D'Sa, E. J., R. G. Steward, A. Vodacek, N. V. Blough, and D. Phinney (1999), Determining optical absorption of colored dissolved organic matter in seawater with a liquid capillary waveguide, Limnol. Oceanogr., 44(4), 1142-1148.

Dunlap, W. C., and J. M. Schick (1998), Ultraviolet radiation-absorbing mycosporine-like amino acids in coral reef organisms: A biochemical and environmental perspective, J. Phycol., 34(3), 418-430, doi:10.1046/ j.1529-8817.1998.340418.x.

Hooker, S. B., et al. (2009), The third SeaWiFS HPLC Analysis RoundRobin experiment (SeaHARRE-3), NASA Technical Memorandum, 2009-215849.

Kishino, M., M. Takahashi, N. Okami, and S. Ichimura (1985), Estimation of the spectral absorption coefficients of phytoplankton in the sea, Bull. Mar. Sci., 37, 634-642.

Kopelevich, O. V., and V. I. Burenkov (1977), Relation between the spectral values of the light absorption coefficients of sea water, phytoplanktonic pigments, and the yellow substance, Oceanology Engl. Transl., 17, 278-282.

Laurion, I., F. Blouin, and S. Roy (2003), The quantitative filter technique for measuring phytoplankton absorption: Interference by MAAs in the UV waveband, Limnol. Oceanogr. Methods, 1, 1-9.

Lee, Z., K. L. Carder, C. D. Mobley, R. G. Steward, and J. S. Patch (1998), Hyperspectral remote sensing for shallow waters. I. A semianalytical model, Appl. Opt., 37(27), 6329-6338, doi:10.1364/AO.37.006329.

Maritorena, S., D. A. Siegel, and A. R. Peterson (2002), Optimization of a semi-analytical ocean color model for global-scale applications, Appl. Opt., 41, 2705-2714, doi:10.1364/AO.41.002705.

Miller, R. L., M. Belz, C. Del Castillo, and R. Trzaska (2002), Determining CDOM absorption spectra in diverse coastal environments using a multiple pathlength, liquid core waveguide system, Cont. Shelf Res., 22, 1301-1310, doi:10.1016/S0278-4343(02)00009-2.

Mitchell, B. G., and D. A. Kiefer (1988), Variability in pigment-specific particulate fluorescence and absorption spectra in the northeastern Pacific Ocean, Deep Sea Res., 35, 665-689, doi:10.1016/0198-0149(88)90025-8. Morel, A., and J. F. Berthon (1989), Surface pigments, algal biomass profiles, and potential production of the euphotic layer: Relationships reinvestigated in view of remote-sensing applications, Limnol. Oceanogr., $34,1545-1562$

Morel, A., and A. Bricaud (1981), Theoretical results concerning light absorption in a discrete medium, and application to specific absorption of phytoplankton, Deep Sea Res., 28, 1375-1393, doi:10.1016/01980149(81)90039-X.

Morel, A., and B. Gentili (2009), A simple band ratio technique to quantify the colored dissolved and detrital organic material from ocean color remotely sensed data, Remote Sens. Environ., 113(5), 998-1011, doi:10.1016/j.rse.2009.01.008. 
Morel, A., B. Gentili, H. Claustre, M. Babin, A. Bricaud, J. Ras, and F. Tièche (2007a), Optical properties of the "clearest" natural waters, Limnol. Oceanogr., 52(1), 217-229.

Morel, A., H. Claustre, D. Antoine, and B. Gentili (2007b), Natural variability of bio-optical properties in case 1 waters: Attenuation and reflectance within the visible and near-UV spectral domains, as observed in South Pacific and Mediterranean waters, Biogeosciences, 4, 913-925.

Nelson, N. B., and D. A. Siegel (2002), Chromophoric DOM in the ocean, in Biogeochemistry of Marine Dissolved Organic Matter, edited by D. A. Hansell and C. A. Carlson, pp. 547-578, Academic, San Diego, Calif., doi:10.1016/B978-012323841-2/50013-0.

Nelson, N. B., D. A. Siegel, and A. F. Michaels (1998), Seasonal dynamics of colored dissolved material in the Sargasso Sea, Deep Sea Res. Part I, 45, 931-957, doi:10.1016/S0967-0637(97)00106-4.

Parslow, J. S., L. A. Clementson, A. R. Turnbull, and D. C. McKenzie (1998), Optical characteristics of oceans around Australia, paper presented at Ocean Optics XIV, S. Ackleson and J. Campbell eds., Office of Naval Research, Washington D. C., Kailua-Kona, Hawaii, November.

Pegau, S. (1996), The distribution of colored dissolved organic matter (CDOM) in the equatorial Pacific, in Ocean Optics XIII, Proc. SPIE, 2963, 508-513.

Pegau, W. S., G. Deric, and J. R. V. Zaneveld (1997), Absorption and attenuation of visible and near-infrared light in water: Dependence on temperature and salinity, Appl. Opt., 36(24), 6035-6046, doi:10.1364/ AO.36.006035.

Pope, R. M., and E. S. Fry (1997), Absorption spectrum 380-700 nm of pure water. II. Integrating cavity measurements, Appl. Opt., 36(33), 8710-8723, doi:10.1364/AO.36.008710.

Prieur, L., and S. Sathyendranath (1981), An optical classification of coastal and oceanic waters based on the specific spectral absorption curves of phytoplankton pigments, dissolved organic matter, and other particulate materials, Limnol. Oceanogr., 26, 671-689.

Raimbault, P., N. Garcia, and F. Cerutti (2008), Distribution of inorganic and organic nutrients in the South Pacific Ocean-evidence for longterm accumulation of organic matter in nitrogen-depleted waters, Biogeosciences, 5, 281-298.

Ras, J., J. Uitz, and H. Claustre (2008), Spatial variability of phytoplankton pigment distributions in the subtropical South Pacific Ocean: Comparison between in situ and modelled data, Biogeosciences, 5, 353-369.

Reynolds, R. A., D. Stramski, and B. G. Mitchell (2001), A chlorophylldependent semianalytical reflectance model derived from field measurements of absorption and backscattering coefficients within the Southern Ocean, J. Geophys. Res., 106(C4), 7125-7138, doi:10.1029/1999JC000311.

Roesler, C. S., M. J. Perry, and K. L. Carder (1989), Modeling in situ phytoplankton absorption from total absorption spectra in productive inland marine waters, Limnol. Oceanogr., 34, 1510-1523.

Sathyendranath, S., G. Cota, V. Stuart, H. Maass, and T. Platt (2001), Remote sensing of phytoplankton pigments: A comparison of empirical and theoretical approaches, Int. J. Remote Sens., 22(2\&3), 249-273, doi:10.1080/014311601449925

Siegel, D. A., S. Maritorena, N. B. Nelson, D. A. Hansell, and M. LorenziKayser (2002), Global distribution and dynamics of colored dissolved and detrital organic materials, J. Geophys. Res., 107(C12), 3228, doi:10.1029/2001JC000965.

Simeon, J., C. Roesler, W. S. Pegau, and C. Dupouy (2003), Sources of spatial variability in light absorbing components along an equatorial transect from $165^{\circ} \mathrm{E}$ to $150^{\circ} \mathrm{W}, J$. Geophys. Res., 108(C10), 3333 , doi:10.1029/2002JC001613.

Sosik, H. M., M. Vernet, and B. G. Mitchell (1992), A comparison of particulate absorption properties between high- and mid-latitude surface waters, Antarctic J. United States, 27, 162-164.

Twardowski, M. S., and P. L. Donaghay (2002), Photobleaching of aquatic dissolved materials: Absorption removal, spectral alteration, and their interrelationship, J. Geophys. Res., 107(C8), 3091, doi:10.1029/ 1999JC000281.

Twardowski, M. S., E. Boss, J. M. Sullivan, and P. L. Donaghay (2004), Modeling the spectral shape of absorption by chromophoric dissolved organic matter, Mar. Chem., 89, 69-88, doi:10.1016/j.marchem.2004. 02.008 .

Uitz, J., H. Claustre, A. Morel, and S. Hooker (2006), Vertical distribution of phytoplankton communities in open ocean: An assessment based on surface chlorophyll, J. Geophys. Res., 111, C08005, doi:10.1029/ 2005JC003207.

Van Heukelem, L., and C. S. Thomas (2001), Computer-assisted highperformance liquid chromatography method development with applications to the isolation and analysis of phytoplankton pigments, J. Chromatogr. A, 910, 31-49, doi:10.1016/S0378-4347(00)00603-4

Vidussi, F., H. Claustre, B. Manca, A. Luchetta, and J. -C. Marty (2001), Phytoplankton pigment distribution in relation to the upper thermocline circulation in the eastern Mediterranean Sea during winter, J. Geophys. Res., 106(C9), 19,939-19,956, doi:10.1029/1999JC000308.

Vodacek, A., N. V. Blough, M. D. DeGrandpre, E. T. Peltzer, and R. K. Nelson (1997), Seasonal variation of CDOM and DOC in the middle Atlantic Bight: Terrestrial inputs and photooxidation, Limnol. Oceanogr., 42(4), 674-686.

Whitehead, R. F., S. de Mora, S. Demers, M. Gosselin, P. Montfort, and B. Mostajir (2000), Interactions of ultraviolet-B radiation, mixing, and biological activity on photobleaching of natural chromophoric dissolved organic matter: A mesocosm study, Limnol. Oceanogr., 45(2), 278-291.

M. Babin, A. Bricaud, H. Claustre, J. Ras, and F. Tièche, Laboratoire d'Océanographie de Villefranche, Université Pierre et Marie Curie-Paris 6 , CNRS, BP 08, 06238 Villefranche-sur-Mer, France. (annick.bricaud@ obs-vlfr.fr) 